\title{
STANDARDIZATION APPROACHES IN ABSOLUTE QUANTITATIVE PROTEOMICS WITH MASS SPECTROMETRY
}

AUTHORS: Francisco Calderón-Celis, Jorge Ruiz Encinar,* Alfredo Sanz-Medel

Department of Physical and Analytical Chemistry, University of Oviedo, Julián Clavería 8, 33006 Oviedo, Spain

*Corresponding author. Phone: +34-985103069. E-mail: ruizjorge@uniovi.es 


\section{TABLE OF CONTENTS}

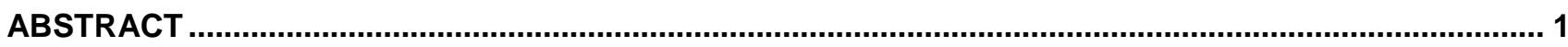

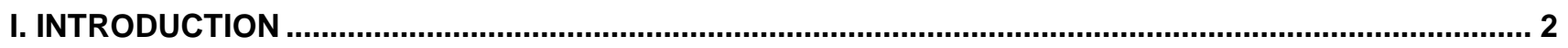

A. The role of mass spectrometry in quantitative proteomics ............................................................................. 3

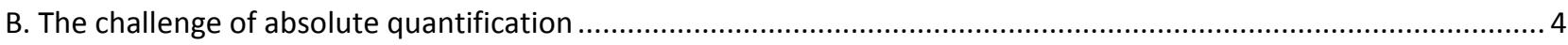

II. NON-ISOTOPE LABELED STANDARDIZATION APPROACHES ................................................... 5

A. Non-isotope labeled standardization approaches with molecular mass spectrometry ..................................... 6

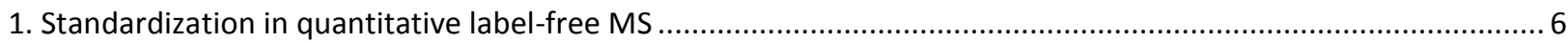

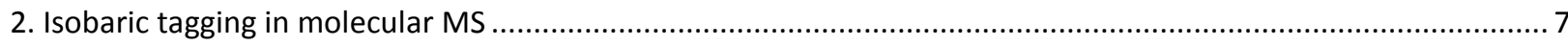

B. Non-isotope labeled standardization approaches with elemental mass spectrometry ....................................... 8

1. Direct quantification of peptide/proteins using elemental MS ............................................................... 8

2. Direct protein tagging for ICP-MS based quantification ......................................................................... 10

3. Antibody tagging in immunoassay approaches with ICP-MS detection .................................................... 11

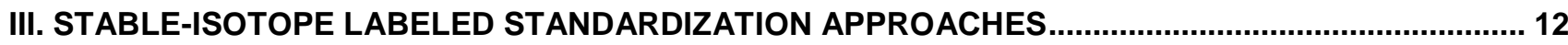

A. Stable-isotope labeled standardization approaches with molecular mass spectrometry .................................... 13

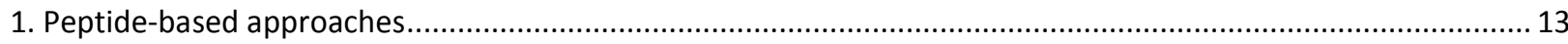

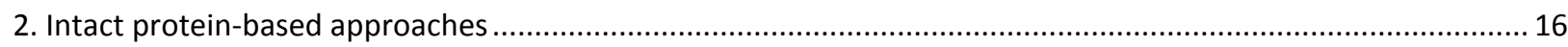

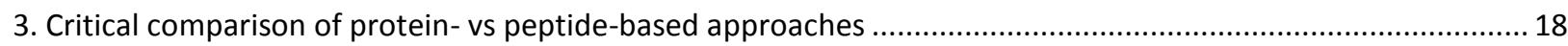

4. The potential to combine label-free strategies and isotope labelling ......................................................... 19

B. Stable-isotope labeled standardization approaches with elemental mass spectrometry ....................................20

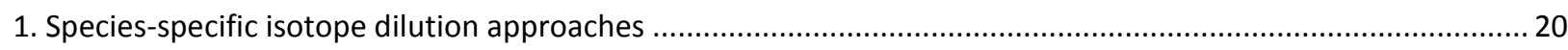

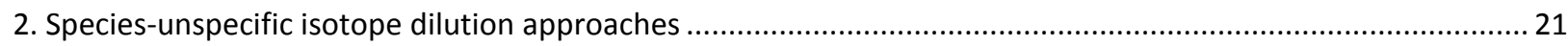

IV. CONCLUDING REMARKS AND FUTURE PROSPECTS............................................................... 22

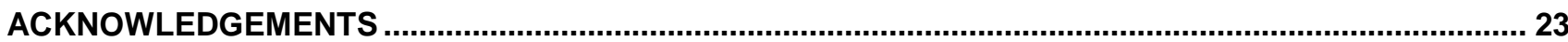

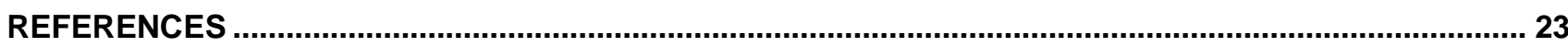

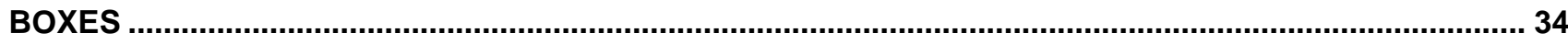

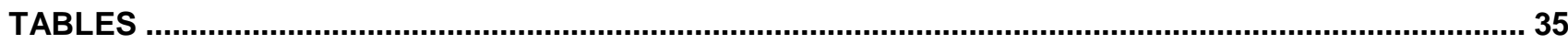

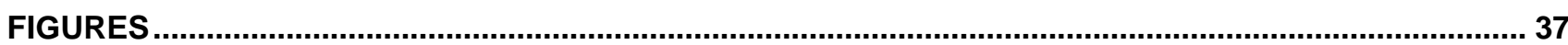




\section{$1 \quad$ ABSTRACT}

2 Mass spectrometry-based approaches have enabled important breakthroughs in quantitative proteomics in the last 3 decades. This development is reflected in the better quantitative assessment of protein levels as well as to understand 4 post-translational modifications and protein complexes and networks. Nowadays, the focus of quantitative proteomics 5 shifted from the relative determination of proteins (i.e., differential expression between two or more cellular states) to 6 absolute quantity determination, required for a more-thorough characterization of biological models and comprehension 7 of the proteome dynamism, as well as for the search and validation of novel protein biomarkers. However, the physico8 chemical environment of the analyte species affects strongly the ionization efficiency in most mass spectrometry (MS) 9 types, which thereby require the use of specially designed standardization approaches to provide absolute quantifications. 10 Most common of such approaches nowadays include (i) the use of stable isotope-labeled peptide standards, isotopologues 11 to the target proteotypic peptides expected after tryptic digestion of the target protein; (ii) use of stable isotope-labeled protein standards to compensate for sample preparation, sample loss, and proteolysis steps; (iii) isobaric reagents, which after fragmentation in the MS/MS analysis provide a final detectable mass shift, can be used to tag both analyte and standard samples; (iv) label-free approaches in which the absolute quantitative data are not obtained through the use of any kind of labeling, but from computational normalization of the raw data and adequate standards; (v) elemental mass spectrometry-based workflows able to provide directly absolute quantification of peptides/proteins that contain an ICPdetectable element. A critical insight from the Analytical Chemistry perspective of the different standardization approaches and their combinations used so far for absolute quantitative MS-based (molecular and elemental) proteomics is provided in this review.

Keywords: Quantitative proteomics, mass spectrometry, isotope labeling, absolute quantification

Abbreviations: MS: mass spectrometry, HPLC: high-performance liquid chromatography, SRM: selected reaction monitoring, MRM: multiple reaction monitoring, ESI: electrospray ionization, MALDI: matrix-assisted laser dissociation/ionization, IDMS: isotope dilution mass spectrometry, SIL: stable-isotope labeled, ICP-MS: inductively coupled plasma mass spectrometry, PTM: post-translational modification. 


\section{$1 \quad$ I. INTRODUCTION}

2 A main scientific challenge is the understanding of an organism. The sequencing of human genome (Lander et al. 2001,

3 Venter et al. 2001) implied a huge step towards this goal, as it led to the identification and mapping of human genes that

4 carry genetic information. Nevertheless, comprehensive study of biological processes cannot be achieved just from the

5 genomics perspective. Different biomolecules play important roles in such processes, among which proteins stand out

6 clearly (Liebler and Yates 2012). Understanding the proteome is therefore sine qua non for a full comprehension and

7 clear view of the processes that occur in an organism.

8 The proteome is, however, much more complex than the genome due to the so-called dynamism of the proteome.

9 Although proteins are gene-translation products, there is no 1-to-1 correspondence because, whereas there are around

1020,000 genes in the human genome, the number of proteoforms might amount up to 1,000,000 (Muñoz and Heck 2014).

11 Once proteins are translated in the ribosomes from mRNA, they can undergo modifications, named post-translational modifications (PTMs), whose extent varies with individual proteins, regulatory mechanisms within the cell, and environmental factors. On the other hand, proteins functions are not based solely on their individual roles or actions, but also from protein-protein interaction networks, which regulate the function and eventual biological activity of the protein components of the network (Jeong et al. 2001). In addition, the diversity in the abundance range of proteins is another with proteomic studies. As an example, human protein levels can vary more than 10 orders of magnitude in serum, from the tens of $\mathrm{mg} \cdot \mathrm{mL}^{-1}$ of albumins to the low $\mathrm{pg} \cdot \mathrm{mL}^{-1}$ interleukins (Anderson and Anderson 2002).

This complexity of the proteome implies that it cannot be understood just from known genomic information. Protein locations or modifications (which are directly responsible for the particular regulation and activity of a given protein), are not visible and barely predictable at the DNA/RNA level. That is, proteomics studies are indispensable to identify the different proteins, to study their regulation mechanisms and possible PTMs, to understand protein-protein interactions and, last but not least, to quantitatively determine protein abundances and protein levels variations in healthy and disease status. In this regard, the eventual construction and elucidation of the human proteome map (Kim et al. 2014, Wilhelm et al. 2014) resulted in a remarkable breakthrough towards functional proteomics understanding.

Protein identification and subsequent generation of protein catalogs have significantly aided one to understand protein biological activity. Nevertheless, this sort of information is not sufficient, and the capability assess not only protein-level variations between two states, but protein absolute quantities is necessary in order to properly address a comprehensive characterization of proteome dynamism (Hoofnagle et al. 2011). The capability to determine protein and PTM quantities might help to assess concentration changes of relevant proteins during biogenesis, in the modifications of cellular states, as well as to reveal biomarker proteins responsible for the appearance of several diseases or even potential targets for drug development to cure such diseases. Moreover, such quantitative information is required for research of biological systems as a whole (systems biology), hence head towards development of mathematical models and algorithms to describe and simulate complex biological processes carried out through proteins (e.g., signaling networks within the cell). 
Traditionally, quantitative proteomics approaches included electrophoresis separations with UV detection (O'Farrell 1975, Von Eggeling et al. 2001), immunochemistry techniques with radioactive, luminescence or fluorescence detection (Yalow and Berson 1960, MacBeath 2002), and immunoblotting techniques. Immunoassays-based techniques have been at the lead in proteomics studies in the last decades, especially since the development of the major immunoassay-based methods used for targeted quantitative proteomics, the enzyme-linked immunosorbent assay (ELISA) (Engvall and Perlmann 1971), and the development of the Western Blotting (Towbin et al. 1979). ELISA's excellent sensitivity and throughput to quantify proteins even at low $\mathrm{pg} \cdot \mathrm{mL}^{-1}$ levels allows for a rather straightforward validation of biomarker candidates if high quality antibodies are available. Moreover, the possibility to study PTMs, protein weight, or location of antibody epitopes provided by Western Blotting have made them both "gold standards" in targeted protein quantification.

Advances in mass spectrometry (MS), genomic sequencing, and bioinformatics have revolutionized proteomics studies in molecular and cell biology research in the last decades. MS-based proteomic approaches can routinely identify thousands of known and novel proteins and/or protein PTMs events contained in biological samples (Aebersold and Mann 2003, Domon and Aebersold 2006). Additionally, MS might provide higher-quality quantitative data because typically, MS experiments can use several peptides of the protein as standards, and the robustness of such peptide assays can be independently verified in each laboratory, study, and sample type. In contrast, the analytical performance of immunoassays-based approaches cannot be properly tested because the antibodies might not be sufficiently characterized, and the specificity and absence of cross-reactivity in the response signal cannot be always assured. Moreover, the observed lack of reproducibility in measurements with different sets of reagents and the unavailability of reference samples have been also highlighted (Hoofnagle and Wener 2009, Aebersold et al. 2013). Still, MS has not completely replaced immunoassays in quantitative proteomics, most notably in clinical analysis and validation, and therefore immunoassay-based techniques remain an important tool in this framework. This situation is the result of insufficient quality assurance of MS-based approaches, which lack controls and calibrators for quantitative results validation (Regnier et al. 2010, Boja et al. 2014).

Even so, MS is the leading trend in proteomics studies and is called to lead in the near future studies of the proteome and functional characterization of biologically important genes. In this sense, molecular-based methods with soft-ionization sources, such as ESI (electrospray ionization) and MALDI (matrix-assisted laser desorption/ionization) are the reference approaches today. The attainable high sensitivity, resolution, and acquisition rates make ESI-MS an exceptionally useful tool to analyze complex proteomic samples, particularly with high-performance liquid chromatography (HPLC) separation, to enable simultaneous and multiplex quantitative detection in a single measurement of target peptides (Pan et al. 2009, Hawkridge 2014). In contrast, MALDI-based MS offers some unique features in proteomics studies, particularly the dissociation of LC separation from sample introduction before MS analysis, to allow separate sample preparation and mass spectrometric analysis. Moreover, MALDI enables a non-destructive sample analysis, the predominant generation of single-charge ions and, very importantly today, the ability to perform targeted protein imaging analysis (Hortin 2006, Gessel et al. 2014). The high sensitivity of the technique, combined with the possibility of direct solid analysis on tissue samples, makes MALDI-MS a powerful technique for protein distribution profiling and biomarkers discovery with differential imaging approaches (Cornett et al. 2007, Franck et al. 2009, Hajduk et al. 2016). 
In parallel with the more-common molecular MS approaches, elemental mass spectrometry with inductively coupled plasma (ICP) ionization is also important for quantitative proteomic analysis, due to its capacity to determine "heteroatoms" (any element in biologicals except $\mathrm{C}, \mathrm{H}, \mathrm{N}$, and $\mathrm{O}$ ) and isotopes present or artificially included (labels) in a given biomolecule. ICP-MS robustness for ionization, which can be translated into quantification without the need for specific standards, is at the basis to explain why ICP-MS is a rising complementary approach to the more widely established molecular-based approaches (Łobiński et al. 2006, Sanz-Medel et al. 2008).

\section{B. The challenge of absolute quantification}

Most quantitative proteomics approaches, especially in large-scale analysis, compare a proteome in a sample under study related to a reference state (Ong and Mann 2005). That is, they are relative quantifications that provide fold changes between target samples (e.g., abundance ratios of the sought protein in both samples), or relative differential expression or regulation of such proteins in at least two compared biological states. Of course, the information provided by such inter-study sample comparisons in the determination of protein contents is only relative unless a standardized reference sample is used. In contrast, an "absolute" quantification to provide actual determination of the total amount or concentration of the individual protein(s) of interest in a single proteome is the focus of present proteomic analysis. Absolute quantification turns up as a more-accurate and -reproducible tool for systems biology applications (Box 1), especially to establish predictive interaction models for such biological systems. In order to build up these models, experimental data and absolute quantitative information on a set of protein concentrations, their changes, their degradation rates, or PTM levels might be of utmost importance (Brönstrup 2004).

In this vein, some approaches adopted for relative quantifications might also be used for absolute quantification (Bantscheff et al. 2012), provided that there are reference standards available for all analytes or their amount added to the samples for the quantitative analysis is known. Such general analytical approaches exploit the well-established concept in analytical chemistry of "internal standardization", in which a known amount of a differentiated, but as similar as possible to the analyte (usually isotope-labeled), well-characterized standard is added to the sample in such a way that the measured response ratio between the target analyte and the standard is used to quantify it in absolute terms. Figure 1 schemes the timeline of such internal standardization in most common molecular MS-based absolute quantitative proteomics approaches.

Most current absolute quantitative proteomics approaches suffer from the hindrance that the analyte is a different chemical species than the standard at the beginning of the experiment. The soundness to translate quantities experimentally obtained (especially after time-consuming sample preparation procedures) into actual quantity of the peptide/protein in the sample is questionable (Zhang et al. 2013). The reliability of the eventual quantification can be greatly affected by protein losses or degradation during sample preparation and/or the completeness of protein digestion if a bottom-up approach is used. In other words, it is still possible that the absolute protein concentration derived from those standard-base MS strategies does not accurately reflect the actual protein level originally present in the biological sample. Therefore, absolute protein quantification is not yet a universal quantification method. As a matter of fact, a large and certified absolute quantification peptide/protein set of standards does not exist yet. Their availability would be the first requisite to apply quality-assurance protocols in quantitative proteomics. In fact, absolute quantifications can only be carried out on a limited number of known target proteins and peptides, and are mainly limited by the need for synthetic and appropriately characterized peptide/protein standard in each case. 


\section{II. NON-ISOTOPE LABELED STANDARDIZATION APPROACHES}

2 MS-based quantitative proteomics today comprises "bottom-up" workflows, in which proteins are enzymatically digested into peptides prior to their MS study, and "top-down" workflows, in which intact proteins are directly analyzed with MS.

4 In targeted "bottom-up" approaches, proteins are mostly identified from a match of masses of observed hydrolyzed 5 peptides and the corresponding MS/MS fragments with theoretical values in a database. Peptide quantification is performed by comparison of the MS peak intensities of the different isotope-labeled (e.g., heavy versus light) peptides. In the specific case of targeted absolute proteomics workflows, previously obtained information on the analyte is used to generate MS-based assays to detect and quantify corresponding predetermined target peptides. Quantification of the target peptides is usually performed through the spike of samples with adequate peptide standards (as "signature" or "proteotypic" peptides) that are chemically synthesized incorporating enriched stable isotopes, and comparing the measured intensities of the light (endogenous) and the heavy (standard) peptides (Schmidt and Urlaub 2012). One of the major downsides of such methods, nonetheless, is that the primary stable isotope-labeled reagents needed for the synthesis are not easy to obtain and are usually expensive. Besides, the cost and time to synthesize, purify, and certify the stable isotope standard peptides for the desired absolute quantitation, as well as setting up spike-in experiments and standard curves, can be substantial. The high cost of the synthesized isotope labeled standards continues to make such determinations of clinically relevant proteins comparatively expensive for routine analysis (Kirkpatrick et al. 2005, Brun et al. 2007).

In this context, the use of the so-called "label-free" approaches is today a clear trend in proteomics, and have the potential to be at the lead of the new developments in quantitative proteomics in the recent future (Cox et al. 2014). These approaches mostly employ computational resources for the quantification by a comparison of the intensity signals or the average spectra matched to a peptide or protein obtained from MS analysis (Bantscheff et al. 2012). However, they might require internal standards for MS signal normalization, because at their current state they still lack the robustness and reproducibility required, and for the production of absolute quantitative data.

Another alternative to the use of SIL standards is to tag directly the tryptic peptides present in different samples with isobaric tags. These tags have a constant overall mass, so that the final mass of the same tryptic peptides present in different samples is still identical and will elute together in the LC-MS analysis after sample mixing (Ong and Mann 2005, Maes et al. 2016a). The different isotopic composition of the component parts of such tags are different, so different MS/MS fragments are observed for each chromatographic peak, which correspond to the different samples analyzed. Hence, multiplex quantification can be carried out. Of course, absolute quantification is affordable if one of the samples analyzed correspond to a standard with known protein concentrations.

Furthermore, ICP-MS-based approaches are currently gaining momentum as they can provide absolute protein quantification without the need for specific standards (stable-isotope labeled or not) and any type of tagging. MS-based quantitative methods that do not make use of stable-isotope labeling are reviewed in the following sections. 


\section{A. Non-isotope labeled standardization approaches with molecular mass spectrometry}

\section{Standardization in quantitative label-free $M S$}

Labeling methodologies require complex, time-consuming sample preparation and reactions and can be relatively expensive. In contrast, label-free quantification is by nature the simplest and more-economical approach. It is, in principle, applicable to any kind of sample, including materials that cannot be labeled, and there is no virtual limit on the number of samples that can be compared/quantified. However, despite the long-standing interest of protein quantification without (isotopic) labels in the proteomics field, the accurate and robust proteome-wide quantification via label-free approaches remains a challenge.

Label-free quantification is generally based on the comparison either of the mass signal intensities (spectrometric spectral counts) for selected proteolytic peptides or the number of peptide-sequencing events observed for the samples/analytes to be analyzed (Chelius and Bondarenko 2002, Aebersold and Mann 2003, Liu et al. 2004). The intensity values of each peptide in one controlled (reference) experiment can be compared with their respective intensities in one or more other experiments to yield relative quantitative information (Neilson et al. 2011, Schilling et al. 2012). With appropriate computational tools, it is possible to infer the difference in protein abundance between two different biological states. The interest in label-free quantification is growing lately because, even though label-free methods suffer from compromised quantification accuracy (because there is less quantitative control in the analytical procedure steps), the label-free algorithms can approximate the protein ratios between samples. Therefore, these methods can be appropriate when large-fold changes are expected and approximate comparisons are enough (Staunton et al. 2014).

Even though these label-free strategies are mostly limited to relative quantification, absolute quantitative approaches have been also reported, such as emPAI (exponentially modified protein abundance index), APEX (absolute protein expression), and iBAQ (intensity-based absolute quantification). emPAI uses an exponential expression that considers the number of observed and observable peptides per protein, which is proportional to the absolute protein abundance and might be converted into absolute concentrations after measuring total protein amounts by BCA assay (Ishihama et al. 2005). APEX is an spectral count method combined with computational normalization, in which absolute protein abundance is obtained from relating the protein abundance in the sample and the number of experimentally obtained and predicted peptide observations per protein ( $\mathrm{Lu}$ et al. 2007). These label-free strategies hold great potential for quantitative proteomics, being able to estimate protein abundance levels with acceptable levels of accuracy (Arike et al. 2012, Fabre et al. 2014), though they still present several practical limitations. High precise, reproducible, and accurate raw data are vital, as well as an exhaustive control and minimization of variations in the sample preparation, chromatographic, and MS performances. These experimental variations, regardless of their source, can be accounted for, provided that appropriate internal standards are used (Ong and Mann 2005, Holman et al. 2016). Table 1 summarized the use of such internal standards in label-free approaches.

On the other hand, iBAQ transforms normalized protein intensities into estimated protein copy numbers, by means of relating the sum of the MS intensities of all peptides matching to a certain protein, and the number of theoretically observable tryptic peptides of the protein (iBAQ intensity) (Schwanhäusser et al. 2011). In this work, iBAQ intensity was correlated to protein quantities by means of using a spike-in commercial protein set standard, hence protein standards concentration was accurately known. These protein standards were used to build a calibration curve (log-iBAQ intensity 

absolute quantities for all proteins identified in the sample.

3 Alternatively, Winter and coworkers introduced a "label-free" quantitative approach, which is based on the use of minimally permuted peptide analogues (MIPA) (Winter et al. 2010). MIPA introduces a positional permutation of two related amino acids on a synthetic standard peptide. Because the amino acid composition of the MIPA and the master peptide is the same, MS ionization efficiency will be very similar. Nevertheless, the fragments produced in the MS/MS analysis will differ due to the differentiation in the peptides sequences produced by the permutation. MIPA-based absolute quantification can be carried out from comparison of peak areas from MS or MS/MS spectra, depending on whether the targeted and MIPA-peptides elute at different retention times or co-elute, respectively.

\section{Isobaric tagging in molecular MS}

During the past few years, several isobaric tagging strategies have been developed and play important roles to compare different biological samples (differential proteomics) that generally resort to shotgun proteomics methods. The masslabeling basis in these procedures is directed by the reactive group of certain amino acids of the protein with the tag. Consequently, such approaches are limited to proteins or peptides that contain those certain amino acid residues. The reporter section of the tagging reagents is different for each sample/protein and provides different fragments in the MS/MS analysis, whereas the "balance" section equilibrates any mass difference, so that every tag (reporter and balance section) has the same final mass.

More than a decade ago, Ross and coworkers (Ross et al. 2004) developed a methodology based on this alternative mode of labeling named iTRAQ (isobaric tag for relative and absolute quantitation). The iTRAQ reagent is tagged to proteins or tryptic peptide sides at the N-terminus amino group and the side chain of Lys (Figure 2.A). The resulting isobarictagged protein/peptides are mixed, and subjected to fractionations and to LC-MS/MS analysis for quantification. Due to the isobaric nature of the labeling reagents, the same peptide from each sample appears as a single peak in the MS spectra. However, after the MS/MS fragmentation, the tags will produce diagnostic, low-mass MS/MS signature ions in such a way that the signal intensity ratios of these signature ions indicate relative proportions (ratios of downregulation or overexpression) of the corresponding peptides/proteins/samples (Wiese et al. 2007). iTRAQ technology enables relative comparison of differential expression levels using different iTRAQ reagents (4- and 8-plex). This approach, however, requires from high accuracy and reproducibility of the LC-MS/MS performance, and the use of an internal standard can be addressed in order to correct for instrumental variations (Fuller and Morris 2012).

Moreover, absolute protein quantification can also be obtained using the iTRAQ workflow (Ross et al. 2004). In this regard, Quaglia and coworkers evaluated the applicability of iTRAQ for absolute protein quantification. They combined the spiking of SIL peptides in a somatropin sample, with iTRAQ derivatization (after tryptic digestion), in order to determine peptide and hence protein concentration from the area ratio of the iTRAQ reagent reporter ion in both, tryptic and SIL peptides. To do so, they used a calibration mixture of two synthetic SIL and non-labeled somatropin peptides, which were treated likewise to the sample, so that quantification could be addressed with both IDMS and iTRAQ approaches. This strategy enabled the validation with IDMS of the iTRAQ-based quantification of somatropin protein. Quantitative results with both approaches were equivalent, though iTRAQ offered lower precision than IDMS (Quaglia et al. 2008). Still, these strategies offer higher accuracy than label-free approaches, which in contrast can provide higher 

underestimation or isotopic impurities of the iTRAQ label (Evans et al. 2012), and by the need of efficient protein digestion, and reproducible and complete protein/peptide derivatizacion (Quaglia et al. 2008).

Together with iTRAQ, isobaric labeling with "tandem mass spectrometry tags" (TMTs) holds great popularity. These tags, similarly to iTRAQ reagents, consist on a peptide-reactive group (NHS ester) and the isobaric tag, which comprises a reporter group (based on N-methylpiperazine) and mass-balance group (Thompson et al. 2003). The reporter and massbalance group masses are different through the use of different isotopes, but in such a way that the mass of the isobaric tag is the same in all the TMT reagents (Figure 2.B). Dayon and coworkers have exploited the quantitative multiplexing capabilities of TMTs -with the use of six-plex isobaric tandem mass tagging (Dayon et al. 2008). Later on, McAllister and coworkers increased the multiplexing capability of the method with ion isotopologues with isobaric masses, in which a ${ }^{15} \mathrm{~N}$ was replaced by a ${ }^{13} \mathrm{C}$, which therefore requires high-accuracy mass spectrometers to resolve the induced mass shift (McAlister et al. 2012); two years later, the use of 10-plex TMT tags was reported (Werner et al. 2014). As was the case with iTRAQ, proof-of-concept of the use of TMTs for absolute quantification was also developed in parallel. In the work by Dayon and coworkers, potential protein biomarkers of brain-damage disorders from cerebrospinal fluid were quantified in absolute terms by means of a calibration curve. To build up this curve, 4 identical mixtures at different concentrations of TMT-labeled synthetic proteotypic peptide standards of such proteins were measured by MS/MS, and therefore relate the reporter ion intensity and the known peptide concentration (Dayon et al. 2010). Despite applicability and linearity of the approach was further validated with standard addition method using synthetic standard peptides, results showed variability among peptides from the same protein, which the authors attributed to different factors, such as the existence of PTMs, the tryptic digestion performance, or the different stability and recovery among peptides.

In the use of isobaric tags, one of the main issues to take care of is the potential errors or effects that might happen during sample preparation, and separations that can affect the quality and validity of the MS/MS quantitative results. These effects can be corrected via statistical approaches or normalization methods of the measured experimental peptides intensities by resorting to constrained optimizations and taking into account information about the labeling strategy (Maes et al. 2016a).

\section{B. Non-isotope labeled standardization approaches with elemental mass spectrometry}

ICP-MS analytical features for elemental trace analysis include potential species-independent signal response of any element-containing species, excellent limits of detection (down to $\mathrm{ng} \cdot \mathrm{L}^{-1}$ ), as well as linear dynamic range of up to 10 orders of magnitude. As a consequence, it is important as a complementary alternative to better-established molecular MS-based quantitative approaches, particularly for absolute quantitative proteomics (Wang et al. 2010). In this regard, ICP-MS can be applied to quantify virtually all proteins by means of the direct determination of naturally present ICPMS-detectable heteroatoms (e.g. metals, S, P, or Se) or after appropriate element tagging to the target species (SanzMedel et al. 2012), as schemes Figure 3.

\section{Direct quantification of peptide/proteins using elemental MS}

Even though the four major elements present in proteins $(\mathrm{C}, \mathrm{H}, \mathrm{O}, \mathrm{N})$ cannot be directly measured with ICP-MS, there 
quantitative measurement can be used for the absolute direct quantification of proteins and peptides. Of course, complete species isolation is required because ICP-MS does not distinguish between the elemental signals coming from different co-eluting species. To achieve such protein determination, the corresponding stoichiometry element:protein is required as well. Due to the virtual species-independent nature of the ICP-MS ionization (Sanz-Medel et al. 2012), absolute quantifications can be approached with even inorganic compounds that contain the measured heteroatom as calibration standards (Svantesson et al. 2002).

ICP-MS detection of the non-metallic elements typically present in proteins (i.e., S, P, Se) has been traditionally hampered and only very recent instrumental advances, mostly based on a triple quadrupole configuration for more efficient interference removal (Diez Fernández et al. 2012), enabled their highly sensitive detection. ICP-MS-based studies in quantitative proteomics had been specifically focused on analysis of the metallic and semi-metallic heteroatoms present in (metallo)proteins. Metalloproteins contain coordinated metals (e.g., $\mathrm{Zn}, \mathrm{Fe}, \mathrm{Cu}$, etc.) within the protein structure to provide them with important biological activities (e.g., enzymatic, storage or transport). Consequently, ICP-MS-based quantification of the metallic heteroatom can produce relevant information about its effect in the biological activities and functions of the proteins (Sanz-Medel et al. 2012). Furthermore, the knowledge of the fixed metal:protein stoichiometry enables one to obtain information of protein quantities from the quantitative detection of the metallic heteroatom. Even though ICP-MS-based quantification of metalloproteins is more based on the use of isotope dilution (see III.B section), it is possible to determine the quantity of the metallic heteroatom bound to the protein by means of external calibrations of known concentrations of metalloproteins (Hare et al. 2013, 2016). These studies are limited, nonetheless, by the stability and strength of the protein-heteroatom union through the analytical procedure and measurement, because metal-protein complex instability (especially during the LC separation step) can ruin the quantitative results (Sarmiento-González et al. 2008). Consequently, the possibility to precisely detect heteroatoms covalently joined to the protein structure is of high interest. In this sense, one of the most-promising direct targets for such heteroatom-based quantitative studies is sulfur. Because it is present in cysteine and methionine residues, sulfur is statistically present in almost all proteins. In fact, sulfur is not only a potential candidate for absolute quantification of proteins via ICP-MS, but for special studies of phosphorylation degrees and metalloproteins stoichiometries (Wind et al. 2003, Szpunar 2005). In any case, application of direct sulfur measurement to eventual species quantification is limited by the need to separate with LC the typically very abundant sulfur-containing analytes with quantitative recoveries from the column. This is especially critical in the case of intact protein analysis. Even so, the continuous advances in HPLC together with triple quadrupole ICP-MS technology head towards the possibility of absolute quantification of both peptides (Diez Fernández et al. 2012) and intact proteins (Calderón-Celis et al. 2016). In fact, if correction of the ICP-MS sensitivity along the LC gradient is achieved, absolute quantification of several intact proteins in relatively simple mixtures using a single S-containing generic standard, spiked to the sample prior to the LC-ICP-MS analysis, becomes possible. In this line, hybrid LC-MS configuration with both elemental and molecular MS detection has the potential to in parallel identify and quantify intact proteins directly (Figure 4) (Calderón-Celis et al. 2017). The potential applicability of such approach depends on the availability of robust platforms to achieve pre-MS separation of each and every protein species.

Another important elemental target in quantitative proteomics studies is phosphorous. Unlike sulfur, phosphorous is monoisotopic, i.e., only a single stable isotopic form, ${ }^{31} \mathrm{P}$. The direct measurement of phosphorous in proteins is most relevant today to investigate one of the most important PTM, phosphorylation. Of course, as with sulfur, phosphorylation 
quantification requires the knowledge of stoichiometry phosphorous:protein. Nonetheless, phosphorous is not as common

2 as sulfur in protein structures. This fact is important because it enables one to use phosphorous elemental determination

3 for direct detection (screening) of phosphorylated of proteins in complex biological systems (Maes et al. 2016b).

4 Notably, such approaches also show great potential to assess quantitatively the many procedures commonly used for

5 purification, preconcentration, and/or isolation of peptides in proteomics studies, as already demonstrated specifically for phosphopeptides enrichment strategies (Pereira Navaza et al. 2008).

After prior developments in the ICP-MS analysis of phosphorous for the determination of the phosphorylation degree in proteins (Wind et al. 2001), and the absolute and site-specific quantification of protein phosphorylation (Pereira Navaza et al. 2007, 2008), in 2009 Zinn and coworkers proposed a method based on the use of phosphorous-based absolutely quantified standards peptides (PASTA) for the absolute quantification of phosphorous-containing peptides (phosphorylated peptides) (Zinn et al. 2009). Such synthetic peptides, which were also stable-isotope labeled, could be quantified in absolute terms by calibration with a P-containing generic standard. Once their concentration is certified, these PASTA peptides can be used for quantitative purposes in LC-ESI-MS analyses, after their dephosphorylation with protein phosphatase.

In this line, the recombination of proteins expressed in a selenomethionine-containing media led to exchange of methionine amino acids by selenomethionines to generate standards named RSIQ (recombinant isotope-labeled and selenium-quantified). These standards can also carry an isotopically labeled amino acid (i.e., ${ }^{13} \mathrm{C}$ ) for subsequent use in quantitative proteomics with molecular MS approaches. From the fact that such RSIQ protein standards carry seleniumcontaining amino acids, quantification with ICP-MS measurement of the selenium enables absolute determinations of the selenoprotein as well (Zinn et al. 2010).

\section{1}

\section{Direct protein tagging for ICP-MS based quantification}

Whereas the measurement of naturally present heteroatoms enables direct quantification of proteins, phospho- and selenoproteins and almost any metalloprotein with ICP-MS (Sanz-Medel et al. 2012), the use of non-present heteroatoms as labels offers also some unique features. Artificial elemental labeling enables the quantification of proteins or peptides that otherwise could not be quantified with ICP-MS when the peptide or protein does not contain ICP-detectable heteroatoms, or the required sensitivity cannot be achieved by the direct measurement of naturally present heteroatoms. In this sense, the chemical labeling of the sought peptide/protein molecule with bifunctional reagents that contain the heteroatom (Figure 5.A), mostly rare-earth elements, can enhance the ICP-MS sensitivity due to low ionization potential and lack of interferences. Great multiplexing capabilities due to the number of potential heteroatoms (and isotopes) are also available (Tholey and Schaumlöffel 2010, Sanz-Medel 2016). The potential of this type of labeling and its multiplexing capabilities with ICP-MS detection is clearly shown by the development of a novel "mass cytometry" technique, as an alternative to conventional flow cytometry. This technique consists of the labeling of cell components with recognition molecules (mostly antibodies) that carry rare earth elements (and isotopes) that enable quantitative analysis with ICP and a ToF-MS analyzer (CyTOF). Thereupon, further understanding of multiple features of cellular systems and multi-parametric biological functions is possible by broadening the experimental toolbox for systems biology investigations (Bendall et al. 2011). 
2 (Ahrends et al. 2007). This complex also contains a reactive group for covalent labeling to the amino acids (Figure 5.B).

3 The protein or peptide quantity is determined directly by the assessment of the metal element signal with ICP-MS.

4 Further, Bergmann and coworkers carried out "top-down" and "bottom-up" MeCAT quantifications (Bergmann et al.

5 2012) applying MeCAT labeling to peptides and intact proteins. Metal quantification with FIA-ICP-MS of the lanthanide label amount enabled final absolute protein concentration evaluation.

7 Depending on the nature of the quantitative study, a more-specific tag could be required, as is the case of mercury tags 8 after their bonding to thiol groups of the sought amino acid residues (cysteine). There are some examples of this particular approach that use tags such as small mercury compounds (Guo et al. 2008) or p-hydroxymethilbenzoate

10 (Kutscher and Bettmer 2009) (Figure 5.C). Concerns about toxicity, together with the limited applicability of the approach (selective reactivity to just cysteine), make this tagging a rather academic solution.

Moreover, many peptides might not have a S-reactive group prone to react with a more standard chelating complex (e.g., MeCAT and mercury labeling). Therefore, a wide range of target sites for elemental labeling is desirable. This is the particular case with tyrosine (Tyr)-containing peptides that can selectively react with bis(pyridine)iodonium tetrafluoroborate (IPy2BF4), leading to the bioconjugation of two iodine atoms to the metapositions of the activated aromatic ring. Therefore, iodine labeling can be used to quantify peptides/proteins that contain Tyr amino acids with the ICP-MS measurement of iodine (Figure 5.D). Again, a simple iodine-containing standard, such as iodobenzoic acid, can be used as a generic standard for the Tyr-containing peptides/proteins previously labeled (Pereira Navaza et al. 2009). Interestingly, iodine ICP-MS detection is much more sensitive than phosphorous or sulfur although, in turn, it is less sensitive than lanthanides.

\section{Antibody tagging in immunoassay approaches with ICP-MS detection}

An alternative to heteroatom bioconjugation with the peptide/protein of interest is the use of bifunctional reagents, which contain the heteroatom bound to an adequate protein-recognition moiety, such as a specific antibody (see Figure 3).

We have already commented that quantification of proteins based on immunoassays have been a major method due to their good sensitivity, selectivity, and throughput, especially the ELISA method. Immunoassays are usually combined with luminescence techniques to provide fast and simple detection. However, it has been demonstrated that ICP-MS detection in immunoassays can overcome some limitations of luminescence detection, such as matrix effects; and therefore they do not require extra sample-preparation steps. Enhanced sensitivity is provided as well (Montoro Bustos et al. 2012). Still, immunoassay-based approaches entail negative issues, inherent to the use of antibodies, that concern cross-reactivity, reagent antibodies saturation, or lack of repeatability among measurements and sensitivity (Hoofnagle and Wener 2009).

Combination of immunoassays with ICP-MS detection was first introduced as an excellent and sensitive alternative for quantitative proteomics (Zhang et al. 2001a). In brief, an antibody that reacts specifically to the target protein is used. This antibody is tagged with an elemental label, which can be measured with ICP-MS. This label can be a metal ion, such as europium (Zhang et al. 2001a), a polymer chain ligand that contains lanthanides (Lou et al. 2007, Majonis et al. 2010) or magnetic nanoparticles that contain the detected heteroatom (Peng et al. 2011), among others. These approaches 
of metal elements in ICP-MS, besides the capability to detect different elemental isotopes to provide multiplexing capabilities (Sanz-Medel 2016). In this vein, Bendall and coworkers have reported the labeling of around 30 (epitopespecific) antibodies with different elements and isotopes for multiplexed cell analysis by ICP-MS-based mass cytometry analysis (Bendall et al. 2011).

In addition, the possibility to use metallic nanoparticles (NPs) as antibody labels instead of single elements allows enhanced sensitivity for protein quantification because they might be formed by thousands of atoms (Sanz-Medel et al. 2008, Liu et al. 2014). Numerous types of NPs with very different and unique physicochemical properties have been used, including gold nanoparticles (AuNPs), silver nanoparticles (AgNPs), silver deposited upon AuNPs, lead nanoparticles (PbNPs), nanoclusters (NCs), and quantum dots (QDs) (López-Serrano et al. 2014). Interestingly, many of those NPs exhibit photoluminescence properties as well. The use of these kind of labels for quantification requires the corresponding bioconjugation reaction between NP and antibody to be well-characterized and under control. Regarding quantification, typical immunoassay calibration curves are typically carried out. However, if the elemental composition of the nanoparticle and the stoichiometry nanoparticle:antibody are known, then the approach has the potential to provide quantification without the need for specific standards because the elemental determination could be directly translated into protein amounts. Still, as in many cases for immunoassays, the selectivity remains an important issue and crossreactivity as well as unspecific interactions are important concerns to take care of.

In addition, if the elemental sensitivity achieved with nanoparticles is not enough, this kind of label enables one to resort to the so-called "amplification" procedures. After the immunoassay has been successfully carried out, the nanoparticle can act as seed, and an elemental layer can be deposited upon it, so that at the end a much bigger nanoparticle is measured. It is worth stressing that the direct use of such bigger nanoparticles is not as effective because the recognition capabilities of the antibody could be compromised. In this manner, the measured analyte contains a much higher number of elemental atoms to amplify enormously the ICP-MS signal and so enhance significantly the detection limits beyond the fg $\mathrm{ml}^{-1}$ level (Garcia-Cortes et al. 2016).

\section{STABLE-ISOTOPE LABELED STANDARDIZATION APPROACHES}

Ever since the introduction of the concept of stable-isotope labeling for the quantification of peptides (Desiderio and Kai 1983), it has become a roaring trend in targeted quantitative proteomics. Typically, the synthetic standard peptides are synthesized with an incorporated stable heavy isotope label (mostly ${ }^{2} \mathrm{H},{ }^{13} \mathrm{C},{ }^{15} \mathrm{~N},{ }^{18} \mathrm{O}$ ) on one or more selected amino acids in their sequences. These synthetic reference standard peptides, or proteins, mimic their endogenous natural counterparts (the analyte), in such a way that they share the same physicochemical properties, including chromatographic co-elution, ionization efficiency, and fragmentation pattern. However, whereas identical chromatographic retention time can be guaranteed with ${ }^{13} \mathrm{C},{ }^{15} \mathrm{~N}$ or ${ }^{18} \mathrm{O}$ labeling (Zhang and Regnier 2002), for ${ }^{2} \mathrm{H}$ labeling the actual retention time might be notoriously changed to likely affect quality of the quantitative results, because conditions at the ESI source will not be identical for both isotopologues (Zhang et al. 2001b).

Such stable-isotope labeled (SIL) standards only differ from the analyte in their isotopic compositions. Therefore, there is a well-known defined mass difference so that they can be unambiguously distinguished and easily detected with MS. 
the sample at a known concentration, the relative ratios of the resulting peptide pairs are a direct measure of the absolute concentration of the target peptides/proteins in such sample. Of course, accuracy of the measurement depends also on the ability to discriminate from possible interfering signals (Mallick and Kuster 2010) in the MS and MSMS spectra. One way to achieve this discrimination is to resort to high mass resolution analyzers or, alternatively, to reduce the sample complexity through sample fractionation or via computational means (Zhang et al. 2010).

\section{A. Stable-isotope labeled standardization approaches with molecular mass spectrometry}

Targeted absolute quantitative proteomics with HPLC-MS make use of such specific isotope-labeled peptides or proteins standards, which are spiked into the sample at known concentration for each targeted peptide or protein to be determined.

\section{Peptide-based approaches}

The vast majority of these strategies resort to synthetic isotope-labeled standards, analogous to proteotypic peptides of the species of interest. The main approaches are AQUA (Absolute Quantification), in which quantification is accomplished by means of spiking the sample with the adequate heavy synthetic peptide (Gerber et al. 2003), and QconCAT (Quantification Concatemer), which makes use of a synthetized isotopically labeled protein built by concatemerization of several proteolytic peptides of the target protein(s) under study (Beynon et al. 2005).

Typically, AQUA methodology consists of addition of the proper synthetic SIL peptide, physically and chemically identical to the endogenous part, and of known concentration, into the experimental sample to obtain absolute quantitative data (Desiderio and Kai 1983, Gerber et al. 2003, Kirkpatrick et al. 2005). Quantification is carried out with MS detection and "selected" (SRM) or "multiple" (MRM) reaction monitoring on the basis of the measured intensity ratio of both peptides, natural and labeled (easily detected as pairs of signals separated by a known and constant $\Delta \mathrm{m}$ ). Because the concentration of the labeled peptide added to the sample is known, the amount of the natural peptide can be determined from the signal ratio. However, one important issue is the initial estimation of the concentration of the labeled standard to be used, because the protein(s) of interest might be present in a broad range of concentration levels in the sample. This limitation can be overcome with a preliminary MRM measurement (Kirkpatrick et al. 2005). Moreover, SIL peptides cannot be used in the initial isolation step of the protein from the sample, and thereby the reproducibility assurance of this sample preparation step is a must.

Typical requisites for such internal standard SIL peptides are: (i) they should be proteotypic in order to avoid peptides with the same sequence from different proteins, (ii) efficiently ionizable in order to provide a good detection by MS, and (iii) peptides with PTMs or that might be subjected to polymorphism should be avoided. The election of the proteotypic peptides to be used as standards in quantitative proteomics is usually approached in an empirical mode, and makes use of those peptides that have been previously sequenced in a shotgun experiment, because chromatographic and ionization properties can be controlled. Nevertheless, if such information is not available, then bioinformatics prediction programs can be used as well to choose potential tryptic peptides (Mallick et al. 2007).

Of course, proteotypic peptides should be previously synthesized and certified. Generation of peptide standards is commonly addressed by stepwise chemical synthesis; solid-phase peptide synthesis (SPPS) is the method of reference (Figure 6.A) (Merrifield 1963). This approach produces peptides through the assembly of the amino acids onto a solid 

enriched peptide standards, they can be generated by using the corresponding isotope labeled amino acids, usually enriched in the C-terminal in Lys or Arg, with ${ }^{15} \mathrm{~N}$ and ${ }^{13} \mathrm{C}$ (Gerber et al. 2003). However, in the course of the chemical synthesis, some peptides can suffer from artificial modifications over time, and several residue- or sequence-dependent side reactions can also occur during the SPPS process, such as the formation of diketopiperazine or aspartimide (Amblard et al. 2006), which results in potential errors in the final absolute measurements. For these reasons, synthesis strategies based on biological, rather than chemical, approaches are popular. These strategies are based on the in vitro expression of an amino acid sequence from a specific gene in a biological media. In the case of isotopically enriched standards, the growing cell culture media is enriched in the desired isotopically enriched amino acids, usually arginine and lysine (metabolic labeling) (Bantscheff et al. 2012). Even though peptides can be directly synthesized with metabolic approaches, the synthesis of proteins (as will be seen later) using their specific encoding gene is more common, as they can be digested after the synthesis in order to produce the target proteotypic peptides.

Once generated the stable isotope-labeled synthetic peptide standards, the concentration of such standard has to be correctly certified in terms of purity in order to obtained accurate quantitative results. The most-common and -extended approach for peptide/protein certification is amino acid analysis (AAA), which provides quantitative information on the amino acid content of peptides or proteins as well as their amino acid composition after a hydrolysis step (mostly acid) to break the peptide bonds of the peptides or proteins. AAA presents a series of issues to take into account, such as (i) the acid hydrolysis, which can produce chemical modifications or degradations in the amino acids when too rough conditions are employed, obligating to the control and optimization of this procedure (Rutherfurd and Gilani 2009); (ii) the low efficiency of the acid hydrolysis for long amino acid sequences, which hampers the applicability of AAA to intact proteins quantification; (iii) the high amount of starting materials; (iv) its lack of specificity, because AAA detects aminoacids independently of the original peptide; and (v) the requirement for highly purified peptides, which usually implies purity assessment (Fountoulakis and Lahm 1998, Mirzaei et al. 2008). An alternative approach to amino acid analysis is chemiluminescent nitrogen detection (CLN). CLN enables the direct determination of the peptide content even in crude mixtures in contrast to AAA. The CLN approach consists of the burning of the compounds to achieve combustion of the nitrogen. Nitric oxide species formed react with ozone in a specific chemiluminescent reaction and emit light in the red and infrared region of spectrum. The intensity measured with a photomultiplier tube is directly proportional to the amount of nitrogen in the sample (Fujinari et al. 1996). Nevertheless, the methodology lacks robustness and selectivity, because any compound in the sample that contains nitrogen would contribute to the signal emitted, including those containing ammonia, hydrazine, or nitrogen oxides.

On the other hand, the proven advantageous features of elemental MS (ICP-MS) for quantitative element detection of heteroatoms point to ICP-MS as an increasingly attractive alternative for protein and peptide standard certification. In this case, given that the signal of the detected element is directly proportional to its absolute amount and independent of the chemical species where it is present, the certification of the concentration of the peptide standards can be directly assessed with calibrations via a single generic standard as simple as an inorganic or organic pure compound (Sanz-Medel et al. 2012). Certification of the peptide concentration through its direct measurement cannot be done unless it contains a heteroatom (any element different from $\mathrm{C}, \mathrm{O}, \mathrm{H}, \mathrm{N}$ and $\mathrm{F}$ ), such as $\mathrm{P}, \mathrm{Se}$, or $\mathrm{S}$. Because most peptides do not contain heteroatoms, their certification is usually carried out via detection of a heteroatom present in a tag chemically joined to the protein with strategies commented on Section II.B. 
An important strength of AQUA is its selectivity and rapid development, even though it is not as sensitive as antibodybased immunoassays (ELISA) when is used directly without any enrichment step. Yet, AQUA can be applied to a wide range of samples, from tissue culture cells to human plasma and tissue; it is limited by instrumentation capabilities; i.e.,

4 the number of proteins that can be measured in a single LC-MS analysis, the duty cycle of the mass spectrometer, and the actual distribution of AQUA peptides across the LC elution profile. In 2004, a method named SISCAPA (Stable Isotope Standards and Capture by Anti-Peptide Antibodies), which combined MRM detection with antibody-based selective enrichment and purification of peptides, was described (Anderson et al. 2004). Briefly, the SIL peptides are spiked to the sample, which is subjected to enzymatic digestion. The proteolyzed sample is incubated in a medium that contains antibodies (affinity columns or conjugated to agarose or magnetic beads) that react specifically to the sought peptides to enable their enrichment. Finally, the enriched peptide is released and analyzed with LC-MS/MS (Whiteaker et al. 2010). The advantage of SISCAPA over common approaches is the possibility to combine the sensitivity and specificity of MRM analysis with the highly selective enrichment capacity of antibodies to produce improved detection limits (Xu et al. 2015).

In contrast to the AQUA approach, QconCAT technique, first described by Beynon and coworkers, is based on the use of artificial proteins, which are concatemers of selected SIL proteotypic peptides characteristic of the target proteins (Beynon et al. 2005). This SIL standard protein is usually synthesized through concatemerization, expressed from a plasmid synthetically prepared that contains the designed artificial genes encoding the different target peptides, that are finally present in the product protein (formed as concatemer of peptides) (Pratt et al. 2006) (Figure 6.B). Nevertheless, there is an alternative approach named PolySIS (polyprotein stable-isotope labeled internal standard), which uses in vitro expression (Anderson and Hunter 2006). After addition to the sample and tryptic digestion, the synthetic protein might provide a SIL standard peptide for each natural proteotypic target peptide/protein, because they carry the isotope label (usually $\left[{ }^{13} \mathrm{C}_{6}\right]$ arginine and $\left[{ }^{13} \mathrm{C}_{6}\right]$ lysine) from the moment they were expressed.

One of the main concerns in QconCAT is to assure an identical digestion between the SIL designed QconCAT protein and the target proteins (Mirzaei et al. 2008). In those cases in which the protein sequence is not fully preserved, and therefore the natural and the labeled proteins both have different amino acid sequences (Scott et al. 2015), the tryptic digestion efficiency might be affected, especially if the differences in the sequence surround the cleavage sites (Keil 1992) of the target peptides. The importance to assure identical digestion conditions in order to obtain equimolarity of QconCAT peptides, has led to the inclusion of natural flanking sequences around the cleavage sites of the QconCAT protein to better mimic the target protein (Achour et al. 2015). In 2007, the peptide-concatemer standards (PCS) (Kito et al. 2007) strategy was developed for the accurate quantification of the stoichiometry of the components of the QconCAT protein with MS. In this strategy, these PCS standards do not only include the SIL tryptic peptides as potential internal standards for quantification of the target proteins as happens with QconCAT, but also their natural flanking sequences. Therefore, the cleavage efficiency of the PCS and the target protein is in principle matched to improve quantification accuracy. Consequently, errors in the digestion efficiency and existence of miscleavages can be better corrected, because the adjacent aminoacids (which will be cut by the enzyme) are included in both the natural and the standard peptide. With the use of the PCS strategy, quantitative information regarding the stoichiometry of the components of a multiprotein system can be obtained and what is more important, eventual absolute analytes quantification might be also provided. In any case, purification and gene-construction processes are limited by larger PCS. For instance, in the study 

the sample is required.

3 An important issue that affects not only AQUA and QconCAT, but also any targeted quantitative proteomics approach, is 4 the selection of the peptide standard for quantification. Computational approaches to predict peptides likely to be observed using MS are clearly desirable. In this regard, a series of repositories that contain a compendium of MS/MS proteomics data are available, such as PeptideAtlas (Desiere et al. 2004, 2006), SRMAtlas (Picotti et al. 2008), or PRIDE (Protein Identifications Database) (Martens et al. 2005). PeptideAtlas is a database framework that contains peptides sequences and MS/MS data from proteomic experiments. This resource is of public access, so that raw data from different scientists can be accepted into the repository. Such data are processed and reanalyzed, and finally gathered in a compendium library (Deutsch et al. 2008). In relation to PeptideAtlas, SRMAtlas is a database that contains specific information of proteomics assays based on the analysis of proteomes digests with tandem (SRM/MRM) MS, whereas PRIDE is a database that contains proteomics data on protein/peptide identification as well as localization of PTMs. These public resources can facilitate the production of predictive algorithms for proteomic analysis, as well as the estimation of the optimal proteotypic peptides when designing targeted proteomics experiments. To address these points in QconCAT, Eyers and coworkers have generated two complementary data sets of proteotypic peptides and developed CONSeQuence, a consensus prediction system built around four independent machine-learning algorithms to better understand peptide "detectability" (Eyers et al. 2011).

Because absolute quantification of proteins using labeled peptides is carried out through the measured intensity ratio between the natural and labeled peptides, and this ratio is related to the label peptide concentration in order to determine the target protein concentration in the sample, spectral overlapping of both peptides must be avoided. For that purpose, the isotopically labeled analog usually carries multiple tags. Nonetheless, this multi-isotopic labeling can lead to isotopic effects and hence errors in the measurement of the intensity ratio; thereby methodological calibrations are needed to correlate the intensity and molar ratios of both peptides (Kuhn et al. 2004). In this sense, González-Antuña and coworkers developed a strategy based on spectral overlapping between the natural and isotopically labeled peptides, which are minimally labeled in ${ }^{13} \mathrm{C}$ and named MOPs (mapped overlapping peptides) to avoid isotopic effects. This strategy allowed determination of the molar fractions of both peptide abundances directly from the experimental mass spectra without need for instrumental calibration (González-Antuña et al. 2015).

\section{Intact protein-based approaches}

Whereas the use of SIL peptides as quantification standards in approaches such as AQUA and QconCAT is the main strategy today in absolute quantitative shotgun proteomics, it has some limitations: incomplete coverage of the protein sequence, the need to characterize and control the proteolysis step efficiency, and the lack of control over samplepreparation steps previous to digestion. Thereby, the natural alternative to overcome such drawbacks is the use of intact (full-length) SIL protein standards.

The common workflow consists of the addition in known concentrations of the synthetic SIL protein standard to the sample, at the earliest steps of the analytical process (e.g., to the lysate, tissue, or biological fluid, that contain the sample proteins). After sample treatment (extraction, fractionation, etc.), the protein extract is digested into peptides, followed by the LC-MS-MS/MS analysis. Then, absolute quantities of the protein can be determined from the MS ratio of the light 
and heavy versions of the tryptic peptides. The main strategies that make use of SIL full-length proteins in absolute quantitative proteomics are PSAQ (Protein Standard Absolute Quantification) (Brun et al. 2007) and "Absolute SILAC" (Hanke et al. 2008). Additionally, Wang and coworkers recently develop an strategy for absolute protein quantification based on the use of SILAC synthesized SIL proteins and non-labeled protein calibrators, named TAQSI (Targeted absolute quantitative proteomics with SILAC internal standards) (Wang et al. 2016). In this approach, absolute protein quantification is accomplished using the MS ratio of heavy vs light proteolytic peptides of the proteins, and a calibration curve built with the non-labeled protein calibrator set.

As it is the case with peptide-based approaches, availability of the specific SIL protein standards is a limitation in protein-based approaches for absolute proteomics. Full-length protein standard cannot be synthesized with the SPPS stepwise procedure, because it is limited to small peptides (no more than 50-70 residues) as it is impeded by the accumulation of side-products from incomplete acylation and cleavage-related side reactions, as well as the timeconsuming assembling of the amino acid chain. Thus, the synthesis of longer peptides and proteins via chemical procedures has to be addressed by coupling protected segments or, even more efficiently, by chemoselective ligation of non-protected purified sequences to enable a faster assemblage of the peptide chain (Miranda and Alewood 1999). This approach makes use of reactive functionalities in unprotected $~ 50$-residue peptide segments that form the target protein (Figure 6.C). The chemical ligation used to bind them can consist, among others, on the formation of a thioester, an oxime, a directed disulfide, a thioether, a thiazolidine, or a peptide bond in aqueous solution (Dawson and Kent 2000).

Production of SIL proteins to be used as standards is more feasible through biological synthesis, and just requires the specific gene encoding the protein to be available (Miranda and Alewood 1999, Pratt et al. 2006, Lebert et al. 2011). The main approach to biologically synthesized isotopically enriched proteins (peptides) for quantification is SILAC (stable isotope-labeled amino acids for quantification). In this approach, both forms of the proteins (light and heavy) are synthesized in two culture media, one of which contains a heavy form of a specific amino acid, usually $\left[{ }^{13} \mathrm{C}\right]$ Lys and $\left[{ }^{13} \mathrm{C}\right]$ Arg. Such SIL amino acid is incorporated into the proteins, which are likely synthesized under same chemical conditions than those unlabeled proteins in the "light" media with $\left[{ }^{12} \mathrm{C}\right]$ Lys or $\left[{ }^{12} \mathrm{C}\right]$ Arg. For further quantitative purposes, SILAC synthetic proteins need the heavy form of the amino acid to be completely incorporated into its sequence (Ong and Mann 2007). There are also other biological synthesis approaches described besides SILAC, such as the PURE (protein synthesis using recombinant elements) approach, which employs commercial kits for the cell-free in vitro protein expression (Figure 6.D) (Tuckey et al. 2014, Xian et al. 2016); or the FLEXIQuant (Full-Length Expressed Stable-Isotope-labeled Proteins for Quantification) approach, in which the full-length labeled protein standards are expressed in vitro, after the gene of interest is cloned into a wheat germ expression vector, and transcribed and translated in a wheat germ extract (WGE) (Figure 6.E) (Singh et al. 2009).

Likewise to the case of peptides, these synthesized SIL protein standards need to be characterized and certified in order to be used as quantification standards and ensure quality results. Unsuitability of AAA and limitations of CNL to intact protein quantification demand for new strategies for full-length protein standards characterization and certification. In this vein, proven capabilities of ICP-MS for the quantitative analysis of intact proteins (Calderón-Celis et al. 2016) place this methodology as a feasible alternative, because lack of standards for protein certification result in the need for compound-independent approaches. In contrast to peptides, large number of amino acids in the protein sequence entails 

use of non-specific standards.

\section{Critical comparison of protein- vs peptide-based approaches}

4 As commented in the previous sections, both SIL peptide and protein standards allow absolute quantitative proteomics. However, there are sources of error that affect final absolute protein quantitative results depending on the type of SIL standard used. Table 2 summarizes a comparison of the main benefits and limitations of peptides or proteins as standards for absolute quantification.

Quantitative approaches that measure directly intact proteins are still limited today by the necessity of high massaccuracy instruments (such as Fourier transform mass spectrometers, FTMS, or linear ion trap (LTQ-Orbitrap), by the present lack of methods to efficiently fragment large proteins and, above all, by the difficulty to obtain appropriate intact protein standards. Consequently, most quantitative proteomics approaches finally measure tryptic peptides, and make use of tandem-MS instruments (Eng et al. 1994, Perkins et al. 1999). The corresponding SIL peptide standards used for quantification, as shown in Figure 1, can be directly added to the sample (SIL peptides), or can be generated from a protein standard that undergoes tryptic digestion together with the protein samples (SIL proteins).

Due to their higher flexibility and accessibility to chemical modifications, peptides are most efficiently labeled than proteins. Of course, standard peptides are much easier to obtain from chemical synthesis as well. Additionally, the use of peptides instead of proteins provides a better front-end separation and higher sensitivity (Yates et al. 2009). However, there are several key aspects to take into account when peptides are used as standards for absolute-quantitative proteomics: mainly the election of the standard, the enzymatic digestion process, and the analytical recovery of the target proteotypic peptide.

The election of a representative peptide of the protein under study, which normally has to be unique to such protein (the so-called proteotypic peptide), is critical because some amino acid sequences are common to multiple proteins or protein isoforms. Therefore, they cannot be used either as conclusive evidence for the presence of the sought protein or for its specific absolute quantification. Possible PTMs present in the sequence should also be known in order to be used as signature to probe the quantitative state of a PTM associated with a particular biological state or disease setting. In addition, peptides with reactive or labile amino acid residues should be avoided such as those that can suffer oxidation (Met, Cys, and Trp), peptide bond instability (Asp-Pro and Asp-Gly), deamidation (Asp, Glu) or cyclization (N-terminal Glu) (Pan et al. 2009).

Another critical consideration in SIL peptide-based approaches is the needed proteolytic/enzymatic digestion of the target protein. This digestion step involves decomposition of intact proteins into a collection of peptides of suitable size for MS analysis. A 1:1 ratio of the peptide to precursor protein is typically assumed. Therefore, if the digestion is not efficient, and thus the proteotypic peptide is not quantitatively released, it might affect profoundly the precision and accuracy of the final quantification. Consequently, control of denaturing conditions during in-solution hydrolysis is crucial for reliable absolute quantification (Schmidt et al. 2010). In addition, inherent problems associated with protein digestion such as miscleavages at the sites related to the target peptide must be always considered. Another problem associated with protein digestion is the chemical modification of the amino acid side chains during the proteolysis. This 
amount of them eventually detected with MS. Moreover, experimental protocols must be optimized towards high proteolysis kinetic rates in order to avoid bias resulting from, for instance, peptide modification proceeding faster in the SIL internal standard added than in the same stretch of sequence within the intact protein, released as a fragment (Arsene et al. 2008).

Although there are strategies that can simulate the digestion procedure in the peptide standard, by means of incorporating the peptide flanking amino acid sequence (PCS strategy), they cannot simulate the entire molecular environment of the protein. The use of intact proteins as (labeled) internal standards offer here some relevant advantages in comparison to the use of peptides (Table 2) to evaluate and normalize digestion efficiency. Addition of a isotopically labeled version of the sought protein can correct most of the sources of error during digestion procedures, besides from its usefulness as potential standard for quantification (Hoofnagle 2010). Nevertheless, intact protein as standards require the labeled protein must be identical to the endogenous protein and properly and correctly folded. Otherwise, inconsistent tryptic digestion and cleavage efficiency can be produced (Arsene et al. 2008, Yates et al. 2009).

Moreover, it is commonly accepted in quantitative Analytical Chemistry that the sooner the internal standard is added to the sample the better, because more inevitable errors during sample preparation steps would be corrected for. Therefore, a labeled standard should ideally represent the full-length protein, because its use would permit a complete survey and unbiased quantitative analysis (Zhou et al. 2012, Gregorich and Ge 2014). This strategy enables a much better control of the analytical process because the standard is added at the beginning of the process, and shares almost identical biochemical and physicochemical properties with the target protein (Figure 1). Thereby, even prefractionation and digestion steps errors, losses, or procedure inefficiencies before analysis can be corrected. Moreover, direct analysis of intact proteins could lead to a more-reliable quantification of the proteins isoforms and PTMs, because traditional limitations due to the use of peptides for the proteome characterization, including incomplete or ambiguous characterization of alternative splice forms, PTMs and protein cleavages, can be overcome (Tran et al. 2011).

\section{The potential to combine label-free strategies and isotope labelling}

Ideally, peptide's MS signal intensity should be proportional to the absolute abundance of the peptide -and of the corresponding protein- in the sample. However, such an assumption is, in fact, erroneous because of effects such as variable sequence-dependent peptide ionization efficiencies, suppression by co-elution with dominant species, missing observations derived from peak selection in MS/MS analyses, etc. These limitations explain why stable isotope labelling is the most-extensive approach for absolute proteomics. However, although modern MS/MS measurements are sensitive and highly reproducible across laboratories and platforms and they could theoretically be extended to a full proteome, preparation of thousands of isotopically labeled peptides of known concentration is both a formidable and expensive task. In this way, new methodologies based on the use of MS/MS and isotope labeling strategies in combination with computational label-free strategies are popular in order to accomplish a more complete absolute quantification coverage of proteomes (Wepf et al. 2009, Malmström et al. 2009). intensity of its three best-detected peptides (Silva et al. 2005). The spectral-counting approach takes into account the observed counts on a number of MS/MS spectra copies attributable to each protein (Liu et al. 2004) and was improved 

a limited set of SIL internal reference standards, (ii) the average mass spectrum signal intensities of the top three peptides selected per protein, and (iii) weighed MS/MS spectral counts. Thereby, the authors combined the absolute quantification provided by the use of SIL reference peptides with SRM, label-free quantification, and high-throughput proteome sequencing with LC-MS/MS. Such a combination minimizes the costs of isotopic labeling while maximizing coverage and accuracy.

On the other hand, another approach based on the combination of isotope labels and label-free quantification was developed by Wepf and coworkers (Wepf et al. 2009). They quantified bait proteins via isotope-labeled reference peptides corresponded to an affinity tag sequence and prey proteins with label-free correlational quantification with the precursor ion signal intensities of proteotypic peptides generated in reciprocal purifications. Of course, proteotypic peptides must be firstly identified to apply this method. Even though such proteotypic peptides can be computationally predicted or extracted from proteomic databases, they must be experimentally validated. Furthermore, the applicability of SIL reference peptides in the affinity purification coupled to tandem MS (AP-MS/MS) workflow is again limited because their synthesis for a large number of network components is challenging, time-consuming, and expensive (Wepf et al. 2009).

\section{B. Stable-isotope labeled standardization approaches with elemental mass spectrometry}

The ICP-MS capacity to simultaneously measure different isotopes of an element enables absolute quantification of peptide/protein species by the direct measurement of the isotope ratios of the target element in the compound of interest after appropriate addition of an enriched isotope solution, whose concentration and isotopic abundances are accurately known. This quantification is based on the concept of elemental isotope dilution analysis (IDA), which consists of the alteration of the isotope composition of the sample by addition of a known quantity of an isotopically-enriched form of the same element (Figure 7) (García Alonso and Rodríguez-González 2013). From the measurement of the altered isotope ratios of the target element, quantification can be accomplished. Requirements for eventual accurate quantification include the ICP-MS capacity to measure accurately and precisely small variations in that elemental isotope composition. Of course, the isotopes involved in the ratio must be measured free of spectral interferences. In addition, isotope-dilution methods require for equilibration of the natural and isotopically enriched elements, which is easily achieved in the ICP plasma.

There is a wide range of applications in quantitative proteomics based on the elemental IDA concept, mostly classified into two principal workflows (see Figure 3). The first one makes use of an isotopically enriched standard in the same chemical form of the analyte (species-specific IDA). On the contrary, the standard containing the sought element enriched in a heavy isotope is generic without being necessary to be in the same chemical form than the analyte in the second workflow (species-unspecific or online IDA).

\section{Species-specific isotope dilution approaches}

In the first case, as in targeted SIL quantitative proteomics with molecular MS approaches, the labeled or synthetic isotopically enriched form of the target species is spiked into the sample. If this step is done at the beginning of the process, then errors, losses, or matrix effects that occur along all the analytical processes, including sample preparation, 

species and its corresponding isotopically labeled standard will arrive to the ICP source simultaneously to allow for the required elemental isotopic equilibration. In brief, the elemental detection of the different isotopes of the sought element

4 gives an isotopic ratio. Taking into account that the elemental concentration of the added species-specific spike is known as well as the isotope abundances of natural and isotope-labeled versions of the compound (or measured previously), determination of the elemental concentration can be accomplished with this simple elemental isotope ratio measurement with the so-called "isotope dilution equation" (Wang et al. 2010, García Alonso and Rodríguez-González 2013). Such elemental concentrations accurately computed can be translated into biomolecule concentration given the known stoichiometry heteroatom:biomolecule. This approach can be used in quantitative proteomics measuring isotope ratios in elements either naturally present in the peptides/proteins, or tagged to them, usually with reagent molecules. Hence, absolute quantification has been reported for either amino acids (Ruiz Encinar et al. 2004, Hermann et al. 2016), peptides (Deitrich et al. 2016) and even full-length proteins (Harrington et al. 2005, Brauckmann et al. 2016).

\section{Species-unspecific isotope dilution approaches}

On the other hand, quantitative proteomics with species-unspecific isotope dilution using ICP-MS detection is based on use of an online continuous addition, commonly after the on-column separation, of a generic species isotopically enriched in the detected heteroelement, in a known concentration and isotopic composition. Isotopic equilibration required for the IDA computation between the element-containing target species separated during chromatography and the generic isotopically enriched element-containing species added and mixed on-line with the chromatographic eluent is achieved again in the ICP plasma. Thereupon, peptide/protein absolute quantification can be carried out with on-line continuous monitoring (element mass/time) of the isotope ratio, which can be transformed in a mass-flow chromatogram with the mass flow equation, derived from the isotope-dilution equation. Integration of the chromatographic peaks of the different (previously separated) species allows one to calculate directly the mass of the element (Rodríguez-González et al. 2005). This common application of the concept of on-line IDA (Lásztity et al. 1989, Rottmann and Heumann 1994) can be used for absolute quantification of peptides/proteins. Again, it can be applied to elements naturally present, such as iron (Grebe et al. 2012) or sulfur (Giner Martínez-Sierra et al. 2010, Feng et al. 2014), or intentionally added after labeling with usually lanthanide-containing species such as europium (Patel et al. 2008) or lutetium (Rappel and Schaumlöffel 2009). This controlled labeling enables quantification of any peptide species, unlike direct quantification with naturally present elements, in which only peptides or proteins that contain that target element can be quantified. Given the virtually species-independent nature of ICP ionization, and that the spike is normally added after the chromatographic separation, this spike does not require the same chemical form than that of the studied species. Consequently, several different peptide/protein species can be quantified in one analysis and without the need for specific (labelled or not) standards. Nevertheless, the identity of the species is finally necessary in order to translate the quantified amount of element in each chromatographic peak into compound quantity, usually accomplished with parallel molecular mass spectrometry approaches. In that sense, Figure 4 shows a model workflow that described the synergic combination of elemental MS, which provides quantitative information, and molecular MS, enabling identity and sequence characterization of the species, as has already been tested for the absolute quantitative profiling of an assayed proteome (Calderón-Celis et al. 2016). 
In brief, these species-unspecific IDA-based ICP-MS approaches hold great potential for the determination of

2 biomolecules for which no specific standards are available or when the synthesis of such standards is too complex or expensive. In fact, ICP-MS capabilities can be of high relevance in quality control and proteomics standard certification.

4 Absolute quantitative data can become directly traceable to the generic element-containing certified standard added to provide consistency of the results and allow for quality-assurance protocols. Of course, such ICP-MS-based approaches are not intended for comprehensive absolute quantification of the whole set of proteins/peptides in complex samples, but can be effectively applied to simpler samples such as the SIL peptide/protein standards produced (see Section III.A) that, once accurately certified, could also be used as internal standards for massive absolute quantifications with LC-MS/MS

9 Furthermore, the scope of those ICP-MS-based approaches has been recently extended to moderately complex samples after demonstration of their potential to simultaneously identify and absolute quantify the proteins of the venoms of elapid snakes. Absolute quantification provided led to the precise determination of the concentration of the different toxins (i.e. 25-30) in the venom without the need for any specific standard (Calderón-Celis et al. 2016, 2017).

\section{IV. CONCLUDING REMARKS AND FUTURE PROSPECTS}

Immunoassay-based techniques for absolute quantitative proteomics have been stablished as the methods of reference for decades, mainly due to their sensitivity, selectivity and experimental simplicity with already-stablished protocols. These approaches are limited not only to specific antibodies availability but also to protein standards of the corresponding targets required to build the immune calibration curves. Therefore, the development of new protocols for quantitative study of new target proteins, such as biomarker potential candidates, can become a laborious and long-lasting task. In this sense, MS has emerged as a powerful technique able to quantitatively characterize up to thousands of proteins in one experiment. Absolute MS-based approaches have thus been described as the techniques to fill the existing gap in the process from biomarker discovery to validation, in which there is a lack of quantitative immunoassay-based protocols (Diamandis 2009). In fact, the potential multiplex for large-scale protein quantification could eventually lead to its implementation in clinical validation of biomarkers, which has been further reinforced by the development of highly accurate MS/MS instrumentation (currently considered as class I -low risk- instrumentation by the FDA). However, there is still insufficient quality control in MS-based approaches to hinder their definitive settlement in legislated clinical protocols (e.g., diagnosis or disease monitoring), mainly due to the limited availability of properly validated quantification standards and (certified) reference materials that could be used as controls (Regnier et al. 2010, Boja et al. 2014).

The use of SIL proteotypic peptide standards remains as the approach of reference in absolute quantitative proteomics with MS. This methodology represents a robust and accurate way to determine peptide/protein absolute quantities in complex samples and can be used even for very low-abundant analytes when combined with enrichment/purification methods like SISCAPA. This kind of quantitative approach requires, however, selection of the standard with MS or MS/MS analysis prior to the quantitative assay. In this sense, several open resources, such as databases and peptides libraries, have emerged recently that entail a significant aid in such task to facilitate the design of quantification assays and protocols in proteomics. Moreover, the possibility to use full-length intact proteins as SIL standards prevents some of the limitations with peptides; e.g., the need to characterize and control the proteolysis step efficiency, and the lack of control over sample-preparation steps previous to digestion. Yet, the use of either SIL peptides or proteins entails the use 
of stable isotope labeling and thus their use is restricted to availability. Alternatively, the use of isobaric tags as labels in quantitative proteomics is acknowledged mainly due to its potential multiplexing capabilities for mostly relative but also absolute quantification of peptides and proteins.

Synthetic production of quantitative standards (labeled or not) can be a simple task because there are a large number of established protocols for peptide (and even protein) synthesis. However, the limited availability of standards for each specific peptide/protein target and robust strategies for their proper characterization are obvious limitations. The outstanding parallel growth of label-free approaches, which are based on computational treatment of the MS data for quantification instead of the use of specific peptide/protein standards, turns them into potential competitors for extensive quantitative proteomics in the near future. It should be stressed that, although label-free quantifications are still plagued today with analytical drawbacks especially in terms of reproducibility and accuracy, it is reasonable to believe that their successful future is engaged to the specific developments of more-efficient bioinformatics tools.

Finally, the certification of the quantification standards is commonly approached with established but cumbersome and prone-to-error techniques. In this regard, the use of ICP-MS can provide a simple, fast, and accurate method to certify the mass purity of such standards. Moreover, the recent synergistic combination of ICP-MS with molecular mass spectrometry has provided absolute quantification of intact proteins even in relatively complex samples without the need for any species-unspecific standards. However, its quantitative capacity is constrained by the resolving power of coupled separation techniques. A major challenge ahead is to develop a robust platform to achieve pre-MS separation of each and every protein species in the sample. On the other hand, the combination of the advantages of ICP-MS detection with the selectivity of element-tagged antibodies provides a most-promising tool to tackle the absolute, sensitive, and robust determination of a few targeted proteins (e.g., panel of biomarkers required for diagnosis and/or prognosis of a given disease).

\section{ACKNOWLEDGEMENTS}

Authors acknowledge financial support of Spanish Ministry of Economy and Competitiveness through CTQ2016-79412-

P and BES-2014-068032 (F.C.C). We thank Prof. Dominic M. Desiderio (University of Tennessee Center for Health

Science) and several anonymous reviewers for constructive comments that improved the original manuscript.

\section{REFERENCES}

Achour B, Al-Majdoub ZM, Al Feteisi H, Elmorsi Y, Rostami-Hodjegan A, Barber J. 2015. Ten years of QconCATs: Application of multiplexed quantification to small medically relevant proteomes. Int. J. Mass Spectrom. 391:93104.

Aebersold R, Burlingame AL, Bradshaw RA. 2013. Western Blots versus Selected Reaction Monitoring Assays: Time to Turn the Tables? Mol. Cell. Proteomics 12:2381-2382.

Aebersold R, Mann M. 2003. Mass spectrometry-based proteomics. Nature 422:198-207.

Ahrends R, Pieper S, Kuhn A, Weisshoff H, Hamester M, Lindemann T, Scheler C, Lehmann K, Taubner K, Linscheid MW. 2007. A Metal-coded Affinity Tag Approach to Quantitative Proteomics. Mol. Cell. Proteomics 6:19071916. 
Amblard M, Fehrentz J-A, Martinez J, Subra G. 2006. Methods and Protocols of Modern Solid Phase Peptide Synthesis. Mol. Biotechnol. 33:239-254.

Anderson L, Hunter CL. 2006. Quantitative Mass Spectrometric Multiple Reaction Monitoring Assays for Major Plasma Proteins. Mol. Cell. Proteomics 5:573-588.

Anderson NL, Anderson NG. 2002. The Human Plasma Proteome: History, Character, and Diagnostic Prospects. Mol. Cell. Proteomics 1:845-867.

Anderson NL, Anderson NG, Haines LR, Hardie DB, Olafson RW, Pearson TW. 2004. Mass Spectrometric Quantitation of Peptides and Proteins Using Stable Isotope Standards and Capture by Anti-Peptide Antibodies (SISCAPA). J. Proteome Res. 3:235-244.

Arike L, Valgepea K, Peil L, Nahku R, Adamberg K, Vilu R. 2012. Comparison and applications of label-free absolute proteome quantification methods on Escherichia coli. J. Proteomics 75:5437-5448.

Arsene CG, Ohlendorf R, Burkitt W, Pritchard C, Henrion A, O’Connor G, Bunk DM, Güttler B. 2008. Protein Quantification by Isotope Dilution Mass Spectrometry of Proteolytic Fragments: Cleavage Rate and Accuracy. Anal. Chem. 80:4154-4160.

Bantscheff M, Lemeer S, Savitski MM, Kuster B. 2012. Quantitative mass spectrometry in proteomics: critical review update from 2007 to the present. Anal. Bioanal. Chem. 404:939-965.

Bendall SC, Simonds EF, Qiu P, Amir E-AD, Krutzik PO, Finck R, Bruggner R V, Melamed R, Trejo A, Ornatsky OI, Balderas RS, Plevritis SK, Sachs K, Pe'er D, Tanner SD, Nolan GP. 2011. Single-Cell Mass Cytometry of Differential Immune and Drug Responses Across a Human Hematopoietic Continuum. Science 332:687-696.

Bergmann U, Ahrends R, Neumann B, Scheler C, Linscheid MW. 2012. Application of Metal-Coded Affinity Tags (MeCAT): Absolute Protein Quantification with Top-Down and Bottom-Up Workflows by Metal-Coded Tagging. Anal. Chem. 84:5268-5275.

Beynon RJ, Doherty MK, Pratt JM, Gaskell SJ. 2005. Multiplexed absolute quantification in proteomics using artificial QCAT proteins of concatenated signature peptides. Nat. Methods 2:587-589.

Boja ES, Fehniger TE, Baker MS, Marko-Varga G, Rodriguez H. 2014. Analytical Validation Considerations of Multiplex Mass-Spectrometry-Based Proteomic Platforms for Measuring Protein Biomarkers. J. Proteome Res. 13:5325-5332.

Brauckmann C, Frank C, Schulze D, Kaiser P, Stosch R, Swart C. 2016. Preparation and characterisation of an 57 Fe enriched haemoglobin spike material for species-specific isotope dilution mass spectrometry. J. Anal. At. Spectrom. 31:1846-1857.

Brönstrup M. 2004. Absolute quantification strategies in proteomics based on mass spectrometry. Expert Rev. Proteomics 1:503-512.

Brun V, Dupuis A, Adrait A, Marcellin M, Thomas D, Court M, Vandenesch F, Garin J. 2007. Isotope-labeled Protein Standards: Toward Absolute Quantitative Proteomics. Mol. Cell. Proteomics 6:2139-2149.

Calderón-Celis F, Cid-Barrio L, Ruiz Encinar J, Sanz-Medel A, Calvete JJ. 2017. Absolute venomics: Absolute quantification of intact venom proteins through elemental mass spectrometry. J. Proteomics.

Calderón-Celis F, Diez-Fernández S, Costa-Fernández JM, Ruiz Encinar J, Calvete JJ, Sanz-Medel A. 2016. Elemental Mass Spectrometry for Absolute Intact Protein Quantification without Protein-Specific Standards: Application to Snake Venomics. Anal. Chem. 88:9699-9706.

Chelius D, Bondarenko P V. 2002. Quantitative Profiling of Proteins in Complex Mixtures Using Liquid Chromatography and Mass Spectrometry. J. Proteome Res. 1:317-323.

Coin I, Beyermann M, Bienert M. 2007. Solid-phase peptide synthesis: from standard procedures to the synthesis of difficult sequences. Nat. Protoc. 2:3247-3256.

Cornett DS, Reyzer ML, Chaurand P, Caprioli RM. 2007. MALDI imaging mass spectrometry: molecular snapshots of biochemical systems. Nat. Methods 4:828-833.

Cox J, Hein MY, Luber C a, Paron I, Nagaraj N, Mann M. 2014. Accurate Proteome-wide Label-free Quantification by Delayed Normalization and Maximal Peptide Ratio Extraction, Termed MaxLFQ. Mol. Cell. Proteomics 13:2513- 
Dawson PE, Kent SBH. 2000. Synthesis of Native Proteins by Chemical Ligation. Annu. Rev. Biochem. 69:923-960.

Dayon L, Hainard A, Licker V, Turck N, Kuhn K, Hochstrasser DF, Burkhard PR, Sanchez J-C. 2008. Relative Quantification of Proteins in Human Cerebrospinal Fluids by MS/MS Using 6-Plex Isobaric Tags. Anal. Chem. 80:2921-2931.

Dayon L, Turck N, Scherl A, Hochstrasser DF, Burkhard PR, Sanchez J-C. 2010. From Relative to Absolute Quantification of Tryptic Peptides with Tandem Mass Tags: Application to Cerebrospinal Fluid. Chim. Int. J. Chem. 64:132-135.

Deitrich CL, Cuello-Nuñez S, Kmiotek D, Torma FA, del Castillo Busto ME, Fisicaro P, Goenaga-Infante H. 2016. Accurate Quantification of Selenoprotein P (SEPP1) in Plasma Using Isotopically Enriched Seleno-peptides and Species-Specific Isotope Dilution with HPLC Coupled to ICP-MS/MS. Anal. Chem. 88:6357-6365.

Desiderio DM, Kai M. 1983. Preparation of stable isotope-incorporated peptide internal standards for field desorption mass spectrometry quantification of peptides in biologic tissue. Biol. Mass Spectrom. 10:471-479.

Desiere F, Deutsch EW, King NL, Nesvizhskii AI, Mallick P, Eng J, Chen S, Eddes J, Loevenich SN, Aebersold R. 2006. The PeptideAtlas project. Nucleic Acids Res. 34:D655-D658.

Desiere F, Deutsch EW, Nesvizhskii AI, Mallick P, King NL, Eng JK, Aderem A, Boyle R, Brunner E, Donohoe S, Fausto N, Hafen E, Hood L, Katze MG, Kennedy KA, Kregenow F, Lee H, Lin B, Martin D, Ranish J a, Rawlings DJ, Samelson LE, Shiio Y, Watts JD, Wollscheid B, Wright ME, Yan W, Yang L, Yi EC, Zhang H, Aebersold R. 2004. Integration with the human genome of peptide sequences obtained by high-thoroughput mass spectrometry. Genome Biol. 6:R9.1-R9.12.

Deutsch EW, Lam H, Aebersold R. 2008. PeptideAtlas: a resource for target selection for emerging targeted proteomics workflows. EMBO Rep. 9:429-434.

Diamandis EP. 2009. Protein Quantification by Mass Spectrometry: Is It Ready for Prime Time? Clin. Chem. 55:14271430 .

Diez Fernández S, Sugishama N, Ruiz Encinar J, Sanz-Medel A. 2012. Triple Quad ICPMS (ICPQQQ) as a New Tool for Absolute Quantitative Proteomics and Phosphoproteomics. Anal. Chem. 84:5851-5857.

Domon B, Aebersold R. 2006. Mass Spectrometry and Protein Analysis. Science 312:212-217.

Von Eggeling F, Gawriljuk A, Fiedler W, Ernst G, Claussen U, Klose J, Römer I. 2001. Fluorescent dual colour 2Dprotein gel electrophoresis for rapid detection of differences in protein pattern with standard image analysis software. Int. J. Mol. Med. 8:373-377.

Eng JK, McCormack AL, Yates JR. 1994. An Approach to Correlate Tandem Mass Spectral Data of Peptides with Amino Acid Sequences in a Protein Database. J. Am. Soc. Mass Spectrom. 5:976-989.

Engvall E, Perlmann P. 1971. Enzyme-linked immunosorbent assay (ELISA) Quantitative assay of immunoglobulin G. Immunochemistry 8:871-874.

Escher C, Reiter L, MacLean B, Ossola R, Herzog F, Chilton J, MacCoss MJ, Rinner O. 2012. Using iRT, a normalized retention time for more targeted measurement of peptides. Proteomics 12:1111-1121.

Evans C, Noirel J, Ow SY, Salim M, Pereira-Medrano AG, Couto N, Pandhal J, Smith D, Pham TK, Karunakaran E, Zou X, Biggs CA, Wright PC. 2012. An insight into iTRAQ: where do we stand now? Anal. Bioanal. Chem. 404:10111027.

Eyers CE, Lawless C, Wedge DC, Lau KW, Gaskell SJ, Hubbard SJ. 2011. CONSeQuence: Prediction of Reference Peptides for Absolute Quantitative Proteomics Using Consensus Machine Learning Approaches. Mol. Cell. Proteomics 10:M110.003384.

Fabre B, Lambour T, Bouyssié D, Menneteau T, Monsarrat B, Burlet-Schiltz O, Bousquet-Dubouch M-P. 2014. Comparison of label-free quantification methods for the determination of protein complexes subunits stoichiometry. EuPA Open Proteomics 4:82-86.

Feng L, Zhang D, Wang J, Li H. 2014. Simultaneous quantification of proteins in human serum via sulfur and iron using HPLC coupled to post-column isotope dilution mass spectrometry. Anal. Methods 6:7655-7662. 
Fountoulakis M, Lahm H-W. 1998. Hydrolysis and amino acid composition analysis of proteins. J. Chromatogr. A 826:109-134.

Franck J, Arafah K, Elayed M, Bonnel D, Vergara D, Jacquet A, Vinatier D, Wisztorski M, Day R, Fournier I, Salzet M. 2009. MALDI Imaging Mass Spectrometry: State of the Art Technology in Clinical Proteomics. Mol. Cell. Proteomics 8:2023-2033.

Fuller HR, Morris GE. 2012. Quantitative Proteomics Using iTRAQ Labeling and Mass Spectrometry. Page in H.-C. Leung, editor. Integrative Proteomics. InTech.

Gallien S, Peterman S, Kiyonami R, Souady J, Duriez E, Schoen A, Domon B. 2012. Highly multiplexed targeted proteomics using precise control of peptide retention time. Proteomics 12:1122-1133.

Garcia-Cortes M, Ruiz Encinar J, Costa-Fernandez JM, Sanz-Medel A. 2016. Highly sensitive nanoparticle-based immunoassays with elemental detection: Application to Prostate-Specific Antigen quantification. Biosens. Bioelectron. 85:128-134.

García Alonso JI, Rodríguez-González P. 2013. Isotope Dilution Mass Spectrometry. The Royal Society of Chemistry, Cambrige, UK.

Gerber SA, Rush J, Stemman O, Kirschner MW, Gygi SP. 2003. Absolute quantification of proteins and phosphoproteins from cell lysates by tandem MS. Proc. Natl. Acad. Sci. 100:6940-6945.

Gessel MM, Norris JL, Caprioli RM. 2014. MALDI Imaging Mass Spectrometry: Spatial Molecular Analysis to Enable a New Age of Discovery. J. Proteomics 107:71-82.

Giner Martínez-Sierra J, Moreno Sanz F, Herrero Espílez P, Santamaria-Fernandez R, Marchante Gayón JM, García Alonso JI. 2010. Evaluation of different analytical strategies for the quantification of sulfur-containing biomolecules by HPLC-ICP-MS: Application to the characterisation of 34S-labelled yeast. J. Anal. At. Spectrom. 25:989.

González-Antuña A, Rodríguez-González P, Ohlendorf R, Henrion A, Delatour V, García Alonso JI. 2015. Determination of Cystatin $\mathrm{C}$ in human serum by isotope dilution mass spectrometry using mass overlapping peptides. J. Proteomics 112:141-155.

Grebe M, Pröfrock D, Kakuschke A, del Castillo Busto ME, Montes-Bayón M, Sanz-Medel A, Broekaert JAC, Prange A. 2012. Comparison of different methods for the absolute quantification of harbour seal transferrin glycoforms using HPLC-ICP-MS. J. Anal. At. Spectrom. 27:440.

Gregorich ZR, Ge Y. 2014. Top-down proteomics in health and disease: Challenges and opportunities. Proteomics $14: 1195-1210$.

Guo Y, Chen L, Yang L, Wang Q. 2008. Counting Sulfhydryls and Disulfide Bonds in Peptides and Proteins Using Mercurial Ions as an MS-tag. J. Am. Soc. Mass Spectrom. 19:1108-1113.

Hahne H, Neubert P, Kuhn K, Etienne C, Bomgarden R, Rogers JC, Kuster B. 2012. Carbonyl-Reactive Tandem Mass Tags for the Proteome-Wide Quantification of N-Linked Glycans. Anal. Chem. 84:3716-3724.

Hajduk J, Matysiak J, Kokot ZJ. 2016. Challenges in biomarker discovery with MALDI-TOF MS. Clin. Chim. Acta 458:84-98.

Hanke S, Besir H, Oesterhelt D, Mann M. 2008. Absolute SILAC for Accurate Quantitation of Proteins in Complex Mixtures Down to the Attomole Level. J. Proteome Res. 7:1118-1130.

Hare DJ, Grubman A, Ryan TM, Lothian A, Liddell JR, Grimm R, Matsuda T, Doble PA, Cherny RA, Bush AI, White AR, Masters CL, Roberts BR. 2013. Profiling the iron, copper and zinc content in primary neuron and astrocyte cultures by rapid online quantitative size exclusion chromatography-inductively coupled plasma-mass spectrometry. Metallomics 5:1656-1662.

Hare DJ, Roberts BR, McColl G. 2016. Profiling changes to natively-bound metals during Caenorhabditis elegans development. RSC Adv. 6:113689-113693.

Harrington CF, Vidler DS, Watts MJ, Hall JF. 2005. Potential for Using Isotopically Altered Metalloproteins in SpeciesSpecific Isotope Dilution Analysis of Proteins by HPLC Coupled to Inductively Coupled Plasma Mass Spectrometry. Anal. Chem. 77:4034-4041. 
Hawkridge AM. 2014. Practical Considerations and Current Limitations in Quantitative Mass Spectrometry-based Proteomics. Pages 3-25in C. E. Eyers and S. Gaskell, editors.Quantitative Proteomics. Royal Society of Chemistry, Cambridge, UK.

Hermann G, Møller LH, Gammelgaard B, Hohlweg J, Mattanovich D, Hann S, Koellensperger G. 2016. In vivo synthesized $34 \mathrm{~S}$ enriched amino acid standards for species specific isotope dilution of proteins. J. Anal. At. Spectrom. 31:1830-1835.

Holman SW, McLean L, Eyers CE. 2016. RePLiCal: A QconCAT Protein for Retention Time Standardization in Proteomics Studies. J. Proteome Res. 15:1090-1102.

Hoofnagle AN. 2010. Quantitative Clinical Proteomics by Liquid Chromatography-Tandem Mass Spectrometry: Assessing the Platform. Clin. Chem. 56:161-164.

Hoofnagle AN, Aebersold R, Anderson NL, Felsenfeld A, Liebler DC. 2011. Painting a Moving Picture: Large-Scale Proteomics Efforts and Their Potential for Changing Patient Care. Clin. Chem. 57:1357-1360.

Hoofnagle AN, Wener MH. 2009. The fundamental flaws of immunoassays and potential solutions using tandem mass spectrometry. J. Immunol. Methods 347:3-11.

Hortin GL. 2006. The MALDI-TOF Mass Spectrometric View of the Plasma Proteome and Peptidome. Clin. Chem. 52:1223-1237.

Ishihama Y, Oda Y, Tabata T, Sato T, Nagasu T, Rappsilber J, Mann M. 2005. Exponentially Modified Protein Abundance Index (emPAI) for Estimation of Absolute Protein Amount in Proteomics by the Number of Sequenced Peptides per Protein. Mol. Cell. Proteomics 4:1265-1272.

Jeong H, Mason SP, Barabási A-L, Oltvai ZN. 2001. Lethality and centrality in protein networks. Nature 411:41-42.

Keil B. 1992. Specificity of Proteolysis. Springer Berlin Heidelberg, Berlin, Heidelberg.

Kim M-S, Pinto SM, Getnet D, Nirujogi RS, Manda SS, Chaerkady R, Madugundu AK, Kelkar DS, Isserlin R, Jain S, Thomas JK, Muthusamy B, Leal-Rojas P, Kumar P, Sahasrabuddhe NA, Balakrishnan L, Advani J, George B, Renuse S, Selvan LDN, Patil AH, Nanjappa V, Radhakrishnan A, Prasad S, Subbannayya T, Raju R, Kumar M, Sreenivasamurthy SK, Marimuthu A, Sathe GJ, Chavan S, Datta KK, Subbannayya Y, Sahu A, Yelamanchi SD, Jayaram S, Rajagopalan P, Sharma J, Murthy KR, Syed N, Goel R, Khan AA, Ahmad S, Dey G, Mudgal K, Chatterjee A, Huang T-C, Zhong J, Wu X, Shaw PG, Freed D, Zahari MS, Mukherjee KK, Shankar S, Mahadevan A, Lam H, Mitchell CJ, Shankar SK, Satishchandra P, Schroeder JT, Sirdeshmukh R, Maitra A, Leach SD, Drake CG, Halushka MK, Prasad TSK, Hruban RH, Kerr CL, Bader GD, Iacobuzio-Donahue CA, Gowda H, Pandey A. 2014. A draft map of the human proteome. Nature 509:575-581.

Kirkpatrick DS, Gerber SA, Gygi SP. 2005. The absolute quantification strategy: a general procedure for the quantification of proteins and post-translational modifications. Methods 35:265-273.

Kito K, Ota K, Fujita T, Ito T. 2007. A Synthetic Protein Approach toward Accurate Mass Spectrometric Quantification of Component Stoichiometry of Multiprotein Complexes. J. Proteome Res. 6:792-800.

Kuhn E, Wu J, Karl J, Liao H, Zolg W, Guild B. 2004. Quantification of C-reactive protein in the serum of patients with rheumatoid arthritis using multiple reaction monitoring mass spectrometry and 13C-labeled peptide standards. Proteomics 4:1175-1186.

Kutscher DJ, Bettmer J. 2009. Absolute and Relative Protein Quantification with the Use of Isotopically Labeled p Hydroxymercuribenzoic Acid and Complementary MALDI-MS and ICPMS Detection. Anal. Chem. 81:91729177.

Lander ES, Linton LM, Birren B, Nusbaum C, Zody MC, Baldwin J, Devon K, Dewar K, Doyle M, FitzHugh W, Funke R, Gage D, Harris K, Heaford A, Howland J, Kann L, Lehoczky J, LeVine R, McEwan P, McKernan K, Meldrim J, Mesirov JP, Miranda C, Morris W, Naylor J, Raymond C, Rosetti M, Santos R, Sheridan A, Sougnez C, StangeThomann N, Stojanovic N, Subramanian A, Wyman D, Rogers J, Sulston J, Ainscough R, Beck S, Bentley D, Burton J, Clee C, Carter N, Coulson A, Deadman R, Deloukas P, Dunham A, Dunham I, Durbin R, French L, Grafham D, Gregory S, Hubbard T, Humphray S, Hunt A, Jones M, Lloyd C, McMurray A, Matthews L, Mercer S, Milne S, Mullikin JC, Mungall A, Plumb R, Ross M, Shownkeen R, Sims S, Waterston RH, Wilson RK, Hillier LW, McPherson JD, Marra MA, Mardis ER, Fulton LA, Chinwalla AT, Pepin KH, Gish WR, Chissoe SL, Wendl MC, Delehaunty KD, Miner TL, Delehaunty A, Kramer JB, Cook LL, Fulton RS, Johnson DL, Minx PJ, Clifton SW, Hawkins T, Branscomb E, Predki P, Richardson P, Wenning S, Slezak T, Doggett N, Cheng J-F, Olsen A, 
Lucas S, Elkin C, Uberbacher E, Frazier M, Gibbs RA, Muzny DM, Scherer SE, Bouck JB, Sodergren EJ, Worley KC, Rives CM, Gorrell JH, Metzker ML, Naylor SL, Kucherlapati RS, Nelson DL, Weinstock GM, Sakaki Y, Fujiyama A, Hattori M, Yada T, Toyoda A, Itoh T, Kawagoe C, Watanabe H, Totoki Y, Taylor T, Weissenbach J, Heilig R, Saurin W, Artiguenave F, Brottier P, Bruls T, Pelletier E, Robert C, Wincker P, Rosenthal A, Platzer M, Nyakatura G, Taudien S, Rump A, Smith DR, Doucette-Stamm L, Rubenfield M, Weinstock K, Lee HM, Dubois J, Yang H, Yu J, Wang J, Huang G, Gu J, Hood L, Rowen L, Madan A, Qin S, Davis RW, Federspiel NA, Abola AP, Proctor MJ, Roe BA, Chen F, Pan H, Ramser J, Lehrach H, Reinhardt R, McCombie WR, de la Bastide M, Dedhia N, Blöcker H, Hornischer K, Nordsiek G, Agarwala R, Aravind L, Bailey JA, Bateman A, Batzoglou S, Birney E, Bork P, Brown DG, Burge CB, Cerutti L, Chen H-C, Church D, Clamp M, Copley RR, Doerks T, Eddy SR, Eichler EE, Furey TS, Galagan J, Gilbert JGR, Harmon C, Hayashizaki Y, Haussler D, Hermjakob H, Hokamp K, Jang W, Johnson LS, Jones TA, Kasif S, Kaspryzk A, Kennedy S, Kent WJ, Kitts P, Koonin E V., Korf I, Kulp D, Lancet D, Lowe TM, McLysaght A, Mikkelsen T, Moran J V., Mulder N, Pollara VJ, Ponting CP, Schuler G, Schultz J, Slater G, Smit AFA, Stupka E, Szustakowki J, Thierry-Mieg D, Thierry-Mieg J, Wagner L, Wallis J, Wheeler R, Williams A, Wolf YI, Wolfe KH, Yang S-P, Yeh R-F, Collins F, Guyer MS, Peterson J, Felsenfeld A, Wetterstrand KA, Myers RM, Schmutz J, Dickson M, Grimwood J, Cox DR, Olson M V., Kaul R, Raymond C, Shimizu N, Kawasaki K, Minoshima S, Evans GA, Athanasiou M, Schultz R, Patrinos A, Morgan MJ. 2001. Initial sequencing and analysis of the human genome. Nature 409:860-921.

Lásztity A, Viczián M, Wang X, Barnes RM. 1989. Sample Analysis by On-line Isotope Dilution Inductively Coupled Plasma Mass Spectrometry. J. Anal. At. Spectrom. 4:761-766.

Lebert D, Dupuis A, Garin J, Bruley C, Brun V. 2011. Production of Use of Stable Isotope-Labeled Proteins for Absolute Quantitative Proteomics. Pages 93-115in K. Gevaert and J. Vandekerckhove, editors.Gel-Free Proteomics. Methods and Protocols. Humana Press, Totowa, NJ.

Liebler DC, Yates JR. 2012. Introduction to Proteomics. Tools for the New Biology. Humana Press, Totowa, NJ.

Liu H, Sadygov RG, Yates JR. 2004. A Model for Random Sampling and Estimation of Relative Protein Abundance in Shotgun Proteomics. Anal. Chem. 76:4193-4201.

Liu R, Wu P, Yang L, Hou X, Lv Y. 2014. Inductively coupled plasma mass spectrometry-based immunoassay: A review. Mass Spectrom. Rev. 33:373-393.

Łobiński R, Schaumlöffel D, Szpunar J. 2006. Mass spectrometry in bioinorganic analytical chemistry. Mass Spectrom. Rev. 25:255-289.

López-Serrano A, Muñoz Olivas R, Sanz Landaluze J, Cámara C. 2014. Nanoparticles: a global vision. Characterization, separation, and quantification methods. Potential environmental and health impact. Anal. Methods 6:38-56.

Lou X, Zhang G, Herrera I, Kinach R, Ornatsky O, Baranov V, Nitz M, Winnik MA. 2007. Polymer-Based Elemental Tags for Sensitive Bioassays. Angew. Chemie Int. Ed. 46:6111-6114.

Lu P, Vogel C, Wang R, Yao X, Marcotte EM. 2007. Absolute protein expression profiling estimates the relative contributions of transcriptional and translational regulation. Nat. Biotechnol. 25:117-124.

MacBeath G. 2002. Protein microarrays and proteomics. Nat. Genet. 32:526-532.

Maes E, Hadiwikarta WW, Mertens I, Baggerman G, Hooyberghs J, Valkenborg D. 2016a. CONSTANd: A Normalization Method for Isobaric Labeled Spectra by Constrained Optimization. Mol. Cell. Proteomics 15:27792790 .

Maes E, Tirez K, Baggerman G, Valkenborg D, Schoofs L, Ruiz Encinar J, Mertens I. 2016b. The use of elemental mass spectrometry in phosphoproteomic applications. Mass Spectrom. Rev. 35:350-360.

Majonis D, Herrera I, Ornatsky O, Schulze M, Lou X, Soleimani M, Nitz M, Winnik MA. 2010. Synthesis of a Functional Metal-Chelating Polymer and Steps toward Quantitative Mass Cytometry Bioassays. Anal. Chem. 82:8961-8969.

Mallick P, Kuster B. 2010. Proteomics: a pragmatic perspective. Nat. Biotechnol. 28:695-709.

Mallick P, Schirle M, Chen SS, Flory MR, Lee H, Martin D, Ranish J, Raught B, Schmitt R, Werner T, Kuster B, Aebersold R. 2007. Computational prediction of proteotypic peptides for quantitative proteomics. Nat. Biotechnol. 25:125-131.

Malmström J, Beck M, Schmidt A, Lange V, Deutsch EW, Aebersold R. 2009. Proteome-wide cellular protein 
concentrations of the human pathogen Leptospira interrogans. Nature 460:762-765.

Martens L, Hermjakob H, Jones P, Adamski M, Taylor C, States D, Gevaert K, Vandekerckhove J, Apweiler R. 2005. PRIDE: The proteomics identifications database. Proteomics 5:3537-3545.

McAlister GC, Huttlin EL, Haas W, Ting L, Jedrychowski MP, Rogers JC, Kuhn K, Pike I, Grothe RA, Blethrow JD, Gygi SP. 2012. Increasing the Multiplexing Capacity of TMTs Using Reporter Ion Isotopologues with Isobaric Masses. Anal. Chem. 84:7469-7478.

Merrifield RB. 1963. Solid Phase Peptide Synthesis. I. The Synthesis of a Tetrapeptide. J. Am. Chem. Soc. 85:21492154.

Miranda LP, Alewood PF. 1999. Accelerated chemical synthesis of peptides and small proteins. Proc. Natl. Acad. Sci. 96:1181-1186.

Mirzaei H, Brusniak M-Y, Mueller LN, Letarte S, Watts JD, Aebersold R. 2009. Halogenated Peptides as Internal Standards (H-PINS): Introduction of an MS-Based Internal Standard Set for Liquid Chromatography-Mass Spectrometry. Mol. Cell. Proteomics 8:1934-1946.

Mirzaei H, McBee JK, Watts J, Aebersold R. 2008. Comparative Evaluation of Current Peptide Production Platforms Used in Absolute Quantification in Proteomics. Mol. Cell. Proteomics 7:813-823.

Montoro Bustos AR, Trapiella-Alfonso L, Ruiz Encinar J, Costa-Fernández JM, Pereiro R, Sanz-Medel A. 2012. Elemental and molecular detection for Quantum Dots-based immunoassays: A critical appraisal. Biosens. Bioelectron. 33:165-171.

Muñoz J, Heck AJR. 2014. From the Human Genome to the Human Proteome. Angew. Chemie Int. Ed. 53:1086410866.

Neilson KA, Ali NA, Muralidharan S, Mirzaei M, Mariani M, Assadourian G, Lee A, van Sluyter SC, Haynes PA. 2011. Less label, more free: Approaches in label-free quantitative mass spectrometry. Proteomics 11:535-553.

O’Farrell PH. 1975. High Resolution Two-Dimensional Electrophoresis of Proteins. J. Biol. Chem. 250:4007-4021.

Ong S-E, Mann M. 2005. Mass spectrometry-based proteomics turns quantitative. Nat. Chem. Biol. 1:252-262.

Ong S-E, Mann M. 2007. A practical recipe for stable isotope labeling by amino acids in cell culture (SILAC). Nat. Protoc. 1:2650-2660.

Pan S, Aebersold R, Chen R, Rush J, Goodlett DR, McIntosh MW, Zhang J, Brentnall TA. 2009. Mass Spectrometry Based Targeted Protein Quantification: Methods and Applications. J. Proteome Res. 8:787-797.

Patel P, Jones P, Handy R, Harrington C, Marshall P, Evans EH. 2008. Isotopic labelling of peptides and isotope ratio analysis using LC-ICP-MS: a preliminary study. Anal. Bioanal. Chem. 390:61-65.

Peng H, Chen B, He M, Zhang Y, Hu B. 2011. Magnetic quantitative immunoanalysis of carcinoembryonic antigen by ICP-MS with mercury labels. J. Anal. At. Spectrom. 26:1217-1223.

Pereira Navaza A, Ruiz Encinar J, Ballesteros A, González JM, Sanz-Medel A. 2009. Capillary HPLC-ICPMS and Tyrosine Iodination for the Absolute Quantification of Peptides Using Generic Standards. Anal. Chem. 81:5390 5399.

Pereira Navaza A, Ruiz Encinar J, Carrascal M, Abián J, Sanz-Medel A. 2008. Absolute and Site-Specific Quantification of Protein Phosphorylation Using Integrated Elemental and Molecular Mass Spectrometry: Its Potential To Assess Phosphopeptide Enrichment Procedures. Anal. Chem. 80:1777-1787.

Pereira Navaza A, Ruiz Encinar J, Sanz-Medel A. 2007. Absolute and Accurate Quantification of Protein Phosphorylation by Using an Elemental Phosphorus Standard and Element Mass Spectrometry. Angew. Chemie Int. Ed. 46:569-571.

Perkins DN, Pappin DJC, Creasy DM, Cottrell JS. 1999. Probability-based protein identification by searching sequence databases using mass spectrometry data. Electrophoresis 20:3551-3567.

Picotti P, Lam H, Campbell D, Deutsch EW, Mirzaei H, Ranish J, Domon B, Aebersold R. 2008. A database of mass spectrometric assays for the yeast proteome. Nat. Methods 5:913-914.

Pratt JM, Simpson DM, Doherty MK, Rivers J, Gaskell SJ, Beynon RJ. 2006. Multiplexed absolute quantification for 
proteomics using concatenated signature peptides encoded by QconCAT genes. Nat. Protoc. 1:1029-1043.

Quaglia M, Pritchard C, Hall Z, O’Connor G. 2008. Amine-reactive isobaric tagging reagents: Requirements for absolute quantification of proteins and peptides. Anal. Biochem. 379:164-169.

Rappel C, Schaumlöffel D. 2009. Absolute Peptide Quantification by Lutetium Labeling and NanoHPLC-ICPMS with Isotope Dilution Analysis. Anal. Chem. 81:385-393.

Regnier FE, Skates SJ, Mesri M, Rodriguez H, Tezak Z, Kondratovich M V, Alterman MA, Levin JD, Roscoe D, Reilly E, Callaghan J, Kelm K, Brown D, Philip R, Carr SA, Liebler DC, Fisher SJ, Tempst P, Hiltke T, Kessler LG, Kinsinger CR, Ransohoff DF, Mansfield E, Anderson NL. 2010. Protein-Based Multiplex Assays: Mock Presubmissions to the US Food and Drug Administration. Clin. Chem. 56:165-171.

Rodríguez-González P, Marchante-Gayón JM, García Alonso JI, Sanz-Medel A. 2005. Isotope dilution analysis for elemental speciation: a tutorial review. Spectrochim. Acta Part B At. Spectrosc. 60:151-207.

Ross PL, Huang YN, Marchese JN, Williamson B, Parker K, Hattan S, Khainovski N, Pillai S, Dey S, Daniels S, Purkayastha S, Juhasz P, Martin S, Barltlet-Jones M, He F, Jacobson A, Pappin DJ. 2004. Multiplexed Protein Quantitation in Saccharomyces cerevisiae Using Amine-reactive Isobaric Tagging Reagents. Mol. Cell. Proteomics 3:1154-1169.

Rottmann L, Heumann KG. 1994. Development of an on-line isotope dilution technique with HPLC/ICP-MS for the accurate determination of elemental species. Fresenius. J. Anal. Chem. 350:221-227.

Ruiz Encinar J, Schaumlöffel D, Ogra Y, Lobinski R. 2004. Determination of Selenomethionine and Selenocysteine in Human Serum Using Speciated Isotope Dilution-Capillary HPLC-Inductively Coupled Plasma Collision Cell Mass Spectrometry. Anal. Chem. 76:6635-6642.

Rutherfurd SM, Gilani GS. 2009. Amino Acid Analysis. Curr. Protoc. Protein Sci. 56:11.9.1-11.9.37.

Sanz-Medel A. 2016. "Heteroatom-tagged" quantification of proteins via ICP-MS. Anal. Bioanal. Chem. 408:53935395 .

Sanz-Medel A, Montes-Bayón M, Bettmer J, Fernández-Sanchez ML, Ruiz Encinar J. 2012. ICP-MS for absolute quantification of proteins for heteroatom-tagged, targeted proteomics. TrAC Trends Anal. Chem. 40:52-63.

Sanz-Medel A, Montes-Bayón M, del Rosario Fernández de la Campa M, Ruiz Encinar J, Bettmer J. 2008. Elemental mass spectrometry for quantitative proteomics. Anal. Bioanal. Chem. 390:3-16.

Sarin VK, Kent SBH, Tam JP, Merrifield RB. 1981. Quantitative Monitoring of Solid-Phase Peptide Synthesis by the Ninhydrin Reaction. Anal. Biochem. 117:147-157.

Sarmiento-González A, Ruiz Encinar J, Cantarero-Roldán AM, Marchante-Gayón JM, Sanz-Medel A. 2008. HPLC-ICPMS and Stable Isotope-Labeled Approaches To Assess Quantitatively Ti(IV) Uptake by Transferrin in Human Blood Serum. Anal. Chem. 80:8702-8711.

Schilling B, Rardin MJ, MacLean BX, Zawadzka a. M, Frewen BE, Cusack MP, Sorensen DJ, Bereman MS, Jing E, Wu CC, Verdin E, Kahn CR, MacCoss MJ, Gibson BW. 2012. Platform-independent and Label-free Quantitation of Proteomic Data Using MS1 Extracted Ion Chromatograms in Skyline: Application to protein acetylation and phosphorylation. Mol. Cell. Proteomics 11:202-214.

Schmidt C, Lenz C, Grote M, Lührmann R, Urlaub H. 2010. Determination of Protein Stoichiometry within Protein Complexes Using Absolute Quantification and Multiple Reaction Monitoring. Anal. Chem. 82:2784-2796.

Schmidt C, Urlaub H. 2012. Absolute Quantification of Proteins Using Standard Peptides and Multiple Reaction Monitoring. Pages 249-265in K. Marcus, editor.Quantitative Methods in Proteomics. Humana Press, Totowa, NJ.

Schwanhäusser B, Busse D, Li N, Dittmar G, Schuchhardt J, Wolf J, Chen W, Selbach M. 2011. Global quantification of mammalian gene expression control. Nature 473:337-342.

Scott KB, Turko I V, Phinney KW. 2015. Quantitative Performance of Internal Standard Platforms for Absolute Protein Quantification Using Multiple Reaction Monitoring-Mass Spectrometry. Anal. Chem. 87:4429-4435.

Silva JC, Gorenstein M V, Li G-Z, Vissers JPC, Geromanos SJ. 2005. Absolute Quantification of Proteins by LCMSE: A Virtue of Parallel MS Acquisition. Mol. Cell. Proteomics 5:144-156. 
Singh S, Kirchner M, Steen JA, Steen H. 2012. A Practical Guide to the FLEXIQuant Method. Pages 295-319in K. Marcus, editor.Quantitative Methods in Proteomics. Humana Press, Totowa, NJ.

Singh S, Springer M, Steen J, Kirschner MW, Steen H. 2009. FLEXIQuant: A Novel Tool for the Absolute Quantification of Proteins, and the Simultaneous Identification and Quantification of Potentially Modified Peptides. J. Proteome Res. 8:2201-2210.

Staunton L, Clancy T, Tonry C, Hernández B, Ademowo S, Dharsee M, Evans K, Parnell AC, Watson RW, Tasken KA, Pennington SR. 2014. Quantitative Proteomics. Page (C. E. Eyers and S. Gaskell, Eds.). Royal Society of Chemistry, Cambridge.

Svantesson E, Pettersson J, Markides KE. 2002. The use of inorganic elemental standards in the quantification of proteins and biomolecular compounds by inductively coupled plasma spectrometry. J. Anal. At. Spectrom. 17:491496.

Szpunar J. 2005. Advances in analytical methodology for bioinorganic speciation analysis: metallomics, metalloproteomics and heteroatom-tagged proteomics and metabolomics. Analyst 130:442-465.

Tabata T, Sato T, Kuromitsu J, Oda Y. 2007. Pseudo Internal Standard Approach for Label-Free Quantitative Proteomics. Anal. Chem. 79:8440-8445.

Tholey A, Schaumlöffel D. 2010. Metal labeling for quantitative protein and proteome analysis using inductivelycoupled plasma mass spectrometry. TrAC Trends Anal. Chem. 29:399-408.

Thompson A, Schäfer J, Kuhn K, Kienle S, Schwarz J, Schmidt G, Neumann T, Hamon C. 2003. Tandem Mass Tags: A Novel Quantification Strategy for Comparative Analysis of Complex Protein Mixtures by MS/MS. Anal. Chem. 75:1895-1904.

Towbin H, Staehelin T, Gordon J. 1979. Electrophoretic transfer of proteins from polyacrylamide gels to nitrocellulose sheets: Procedure and some applications. Proc. Natl. Acad. Sci. 76:4350-4354.

Tran JC, Zamdborg L, Ahlf DR, Lee JE, Catherman AD, Durbin KR, Tipton JD, Vellaichamy A, Kellie JF, Li M, Wu C, Sweet SMM, Early BP, Siuti N, LeDuc RD, Compton PD, Thomas PM, Kelleher NL. 2011. Mapping intact protein isoforms in discovery mode using top-down proteomics. Nature 480:254-258.

Tuckey C, Asahara H, Zhou Y, Chong S. 2014. Protein Synthesis Using a Reconstituted Cell-Free System. Curr. Protoc. Mol. Biol. 108:16.31.1-16.31.22.

Venter JC, Adams MD, Myers EW, Li PW, Mural RJ, Sutton GG, Smith HO, Yandell M, Evans CA, Holt RA, Gocayne JD, Amanatides P, Ballew RM, Huson DH, Wortman JR, Zhang Q, Kodira CD, Zheng XH, Chen L, Skupski M, Subramanian G, Thomas PD, Zhang J, Miklos GLG, Nelson C, Broder S, Clark AG, Nadeau J, McKusick VA, Zinder N, Levine AJ, Roberts RJ, Simon M, Slayman C, Hunkapiller 0 Michael, Bolanos R, Delcher A, Dew I, Fasulo D, Flanigan M, Florea L, Halpern A, Hannenhalli S, Kravitz S, Levy S, Mobarry C, Reinert K, Remington K, Abu-Threideh J, Beasley E, Biddick K, Bonazzi V, Brandon R, Cargill M, Chandramouliswaran I, Charlab R, Chaturvedi K, Deng Z, Francesco V Di, Dunn P, Eilbeck K, Evangelista C, Gabrielian AE, Gan W, Ge W, Gong F, Gu Z, Guan P, Heiman TJ, Higgins ME, Ji R-R, Ke Z, Ketchum KA, Lai Z, Lei Y, Li Z, Li J, Liang Y, Lin X, Lu F, Merkulov G V., Milshina N, Moore HM, Naik AK, Narayan VA, Neelam B, Nusskern D, Rusch DB, Salzberg S, Shao W, Shue B, Sun J, Wang ZY, Wang A, Wang X, Wang J, Wei M-H, Wides R, Xiao C, Yan C, Yao A, Ye J, Zhan M, Zhang W, Zhang H, Zhao Q, Zheng L, Zhong F, Zhong W, Zhu SC, Zhao S, Gilbert D, Baumhueter S, Spier G, Carter C, Cravchik A, Woodage T, Ali F, An H, Awe A, Baldwin D, Baden H, Barnstead M, Barrow I, Beeson K, Busam D, Carver A, Center A, Cheng ML, Curry L, Danaher S, Davenport L, Desilets R, Dietz S, Dodson K, Doup L, Ferriera S, Garg N, Gluecksmann A, Hart B, Haynes J, Haynes C, Heiner C, Hladun S, Hostin D, Houck J, Howland T, Ibegwam C, Johnson J, Kalush F, Kline L, Koduru S, Love A, Mann F, May D, McCawley S, McIntosh T, McMullen I, Moy M, Moy L, Murphy B, Nelson K, Pfannkoch C, Pratts E, Puri V, Qureshi H, Reardon M, Rodriguez R, Rogers Y-H, Romblad D, Ruhfel B, Scott R, Sitter C, Smallwood M, Stewart E, Strong R, Suh E, Thomas R, Tint NN, Tse S, Vech C, Wang G, Wetter J, Williams S, Williams M, Windsor S, Winn-Deen E, Wolfe K, Zaveri J, Zaveri K, Abril JF, Guigo« R, Campbell MJ, Sjolander K V., Karlak B, Kejariwal A, Mi H, Lazareva B, Hatton T, Narechania A, Diemer K, Muruganujan A, Guo N, Sato S, Bafna V, Istrail S, Lippert R, Schwartz R, Walenz B, Yooseph S, Allen D, Basu A, Baxendale J, Blick L, Caminha M, Carnes-Stine J, Caulk P, Chiang Y-H, Coyne M, Dahlke C, Mays AD, Dombroski M, Donnelly M, Ely D, Esparham S, Fosler C, Gire H, Glanowski S, Glasser K, Glodek A, Gorokhov M, Graham K, Gropman B, Harris M, Heil J, Henderson S, Hoover J, Jennings D, Jordan C, Jordan J, Kasha J, Kagan L, Kraft C, Levitsky A, Lewis M, Liu X, Lopez J, Ma D, Majoros W, McDaniel J, Murphy S, Newman M, Nguyen T, Nguyen N, Nodell M, Pan S, Peck J, Peterson M, Rowe W, Sanders R, Scott J, Simpson M, Smith T, Sprague A, Stockwell T, Turner R, 
Venter E, Wang M, Wen M, Wu D, Wu M, Xia A, Zandieh A, Zhu X. 2001. The Sequence of the Human Genome. Science 291:1304-1351.

Wang M, Feng W-Y, Zhao Y-L, Chai Z-F. 2010. ICP-MS-Based strategies for protein quantification. Mass Spectrom. Rev. 29:326-348.

Wang X, Liang Y, Liu L, Shi J, Zhu H-J. 2016. Targeted absolute quantitative proteomics with SILAC internal standards and unlabeled full-length protein calibrators (TAQSI). Rapid Commun. Mass Spectrom. 30:553-561.

Wepf A, Glatter T, Schmidt A, Aebersold R, Gstaiger M. 2009. Quantitative interaction proteomics using mass spectrometry. Nat. Methods 6:203-205.

Werner T, Sweetman G, Savitski MF, Mathieson T, Bantscheff M, Savitski MM. 2014. Ion Coalescence of Neutron Encoded TMT 10-Plex Reporter Ions. Anal. Chem. 86:3594-3601.

Whiteaker JR, Zhao L, Anderson L, Paulovich AG. 2010. An Automated and Multiplexed Method for High Throughput Peptide Immunoaffinity Enrichment and Multiple Reaction Monitoring Mass Spectrometry-based Quantification of Protein Biomarkers. Mol. Cell. Proteomics 9:184-196.

Wiese S, Reidegeld KA, Meyer HE, Warscheid B. 2007. Protein labeling by iTRAQ: A new tool for quantitative mass spectrometry in proteome research. Proteomics 7:340-350.

Wilhelm M, Schlegl J, Hahne H, Gholami AM, Lieberenz M, Savitski MM, Ziegler E, Butzmann L, Gessulat S, Marx H, Mathieson T, Lemeer S, Schnatbaum K, Reimer U, Wenschuh H, Mollenhauer M, Slotta-Huspenina J, Boese J-H, Bantscheff M, Gerstmair A, Faerber F, Kuster B. 2014. Mass-spectrometry-based draft of the human proteome. Nature 509:582-587.

Wind M, Wegener A, Eisenmenger A, Kellner R, Lehmann WD. 2003. Sulfur as the Key Element for Quantitative Protein Analysis by Capillary Liquid Chromatography Coupled to Element Mass SpectrometrySulfur as the Key Element for Quantitative Protein Analysis by Capillary Liquid Chromatography Coupled to Element Mass Spect. Angew. Chemie Int. Ed. 42:3425-3427.

Wind M, Wesch H, Lehmann WD. 2001. Protein Phosphorylation Degree: Determination by Capillary Liquid Chromatography and Inductively Coupled Plasma Mass Spectrometry. Anal. Chem. 73:3006-3010.

Winter D, Seidler J, Kugelstadt D, Derrer B, Kappes B, Lehmann WD. 2010. Minimally permutated peptide analogs as internal standards for relative and absolute quantification of peptides and proteins. Proteomics 10:1510-1514.

Xian F, Zi J, Wang Q, Lou X, Sun H, Lin L, Hou G, Rao W, Yin C, Wu L, Li S, Liu S. 2016. Peptide Biosynthesis with Stable Isotope Labeling from a Cell-free Expression System for Targeted Proteomics with Absolute Quantification. Mol. Cell. Proteomics 15:2819-2828.

Xu Q, Zhu M, Yang T, Xu F, Liu Y, Chen Y. 2015. Quantitative assessment of human serum transferrin receptor in breast cancer patients pre- and post-chemotherapy using peptide immunoaffinity enrichment coupled with targeted proteomics. Clin. Chim. Acta 448:118-123.

Yalow RS, Berson SA. 1960. Immunoassay of Endogenous Plasma Insulin in Man. J. Clin. Invest. 39:1157-1175.

Yates JR, Ruse CI, Nakorchevsky A. 2009. Proteomics by Mass Spectrometry: Approaches, Advances, and Applications. Annu. Rev. Biomed. Eng. 11:49-79.

Zhang C, Wu F, Zhang Y, Wang X, Zhang X. 2001a. A novel combination of immunoreaction and ICP-MS as a hyphenated technique for the determination of thyroid-stimulating hormone (TSH) in human serum. J. Anal. At. Spectrom. 16:1393-1396.

Zhang R, Regnier FE. 2002. Minimizing Resolution of Isotopically Coded Peptides in Comparative Proteomics. J. Proteome Res. 1:139-147.

Zhang R, Sioma CS, Wang S, Regnier FE. 2001b. Fractionation of Isotopically Labeled Peptides in Quantitative Proteomics. Anal. Chem. 73:5142-5149.

Zhang Y, Askenazi M, Jiang J, Luckey CJ, Griffin JD, Marto JA. 2010. A Robust Error Model for iTRAQ Quantification Reveals Divergent Signaling between Oncogenic FLT3 Mutants in Acute Myeloid Leukemia. Mol. Cell. Proteomics 9:780-790.

Zhang Y, Fonslow BR, Shan B, Baek M, Yates JR. 2013. Protein Analysis by Shotgun/Bottom-up Proteomics. Chem. 
Rev. 113:2343-2394.

2 Zhou H, Ning Z, Starr AE, Abu-Farha M, Figeys D. 2012. Advancements in Top-Down Proteomics. Anal. Chem. 3 84:720-734.

4 Zinn N, Hahn B, Pipkorn R, Schwarzer D, Lehmann WD. 2009. Phosphorus-Based Absolutely Quantified Standard 5 Peptides for Quantitative Proteomics. J. Proteome Res. 8:4870-4875.

6 Zinn N, Winter D, Lehmann WD. 2010. Recombinant Isotope Labeled and Selenium Quantified Proteins for Absolute 7 Protein Quantification. Anal. Chem. 82:2334-2340. 
2 BOX 1. Potential areas of interest in biological research benefited from absolute quantitative protein data.

1. Evaluation of protein expression, degradation rates, and variability, and definition of PTMs levels in model biological systems

2. Study of cellular organization and dynamics

3. Determination of protein stoichiometries and ratio variability within protein complexes

4. Study of changes of protein levels and activation status in protein networks

5. Validation of potential new biomarkers and their eventual clinical utility.

6. Study of potential protein therapeutic agents stability (in biological medium, or upon storage)

7. Investigation of enzymes kinetics

8. Development of optimum drug delivery

9. Pharmacokinetic studies on the behaviors of compounds during drug development 
3 Table 1. Internal standardization in label-free approaches to control variations in the sample preparation, chromatographic, and MS 4 performances.

\begin{tabular}{|c|c|c|}
\hline APPROACH & DESCRIPTION & REF. \\
\hline $\begin{array}{c}\text { Retention time score } \\
\text { (iRT) }\end{array}$ & $\begin{array}{l}\text { Empirical normalized values of a set of specific peptides retention } \\
\text { times, that are consistent along different LC configurations enabling } \\
\text { prediction and scaling of peptides chromatographic behavior. }\end{array}$ & $\begin{array}{c}\text { (Escher et al. } \\
\text { 2012) }\end{array}$ \\
\hline $\begin{array}{l}\text { Reversed-phase liquid } \\
\text { chromatography } \\
\text { calibrants (RePLiCal) }\end{array}$ & $\begin{array}{l}\text { Synthetic protein standard that provides peptide calibrant points after } \\
\text { digestion, to normalize retention times, and evaluate and optimize } \\
\text { HPLC performance. }\end{array}$ & $\begin{array}{c}\text { (Holman et al } \\
\text { 2016) }\end{array}$ \\
\hline $\begin{array}{l}\text { Peptide trainer kits } \\
\text { (PTK) }\end{array}$ & $\begin{array}{l}\text { Set of synthetic peptides to predict and correct for dynamic retention } \\
\text { time drifts, re-scheduling the time window that monitor target peptides } \\
\text { in SRM analysis. }\end{array}$ & $\begin{array}{l}\text { (Gallien et al. } \\
\text { 2012) }\end{array}$ \\
\hline $\begin{array}{l}\text { Halogenated peptides } \\
\text { as internal standards } \\
\text { (H-PINS) }\end{array}$ & $\begin{array}{l}\text { Internal standards that contain halogens, taking advantage of their } \\
\text { unique isotopic distribution and mass defect, to be used to evaluate } \\
\text { label-free approaches reproducibility, and to assess labeling reaction } \\
\text { efficiencies }\end{array}$ & $\begin{array}{c}\text { (Mirzaei et al. } \\
\text { 2009) }\end{array}$ \\
\hline $\begin{array}{l}\text { Pseudo Internal } \\
\text { Standards (PISs) }\end{array}$ & $\begin{array}{l}\text { Proteins contained in the sample that do not show variation in } \\
\text { expression levels among different sample states, used as unlabeled } \\
\text { internal standards. They are employed to correct for recovery during } \\
\text { sampling process, as well as for matrix effects. }\end{array}$ & $\begin{array}{l}\text { (Tabata et al. } \\
\text { 2007) }\end{array}$ \\
\hline
\end{tabular}


1 Table 2. Benefits and limitations of using either SIL-peptides or SIL-intact proteins as standards in common mass spectrometry-based quantification approaches. In any case, the final MS measurement is considered to be carried out at the tryptic peptide level.

\section{BENEFITS}

- Applicability to complex samples (thousands of proteins per experiment)

- More flexibility and accessibility to chemical modifications, and easier sequence check out

- Better chromatographic performance and resolution

Peptides (front-end separation) and quantitative analytical recoveries

- Enhanced MS ionization (higher sensitivity)

- Easier synthetic preparation, purification, characterization, and analysis

\section{LIMITATIONS}

- Tryptic digestion efficiency (existence of miscleavages)

- Ambiguity on the origin of redundant peptide sequences

- Extra steps required to determine suitable proteotypic peptides if not available in data bases

- Need for unaltered properties after labeling

- Reactive or labile amino acids are to be avoided

- Later addition does not correct for initial protein losses

- If peptides are low abundant or badly ionized, MS information might lead to inaccurate quantification
- The standard can be added to the crude sample at first stages of the process: full characterization, and correction for losses of protein or tryptic digestion incomplete efficiency

- Complete characterization of the analytical process

Proteins - Possibility to measure at the protein or peptide level (after digestion)

- If protein is digested after spiked, there would be more potentially MS-detectable SIL peptides than if a single SIL peptide is added, thus quantification is statistically more reliable
- Likely non-quantitative analytical recoveries (fractionation and/or separation steps)

- Limited dynamic range (high-abundant proteins might hinder analysis of low-abundant ones)

- Structure has to be identical to the endogenous protein, and properties need to remain unaltered after labeling

- Complicated synthesis labeling, purification, and quantitative certification 


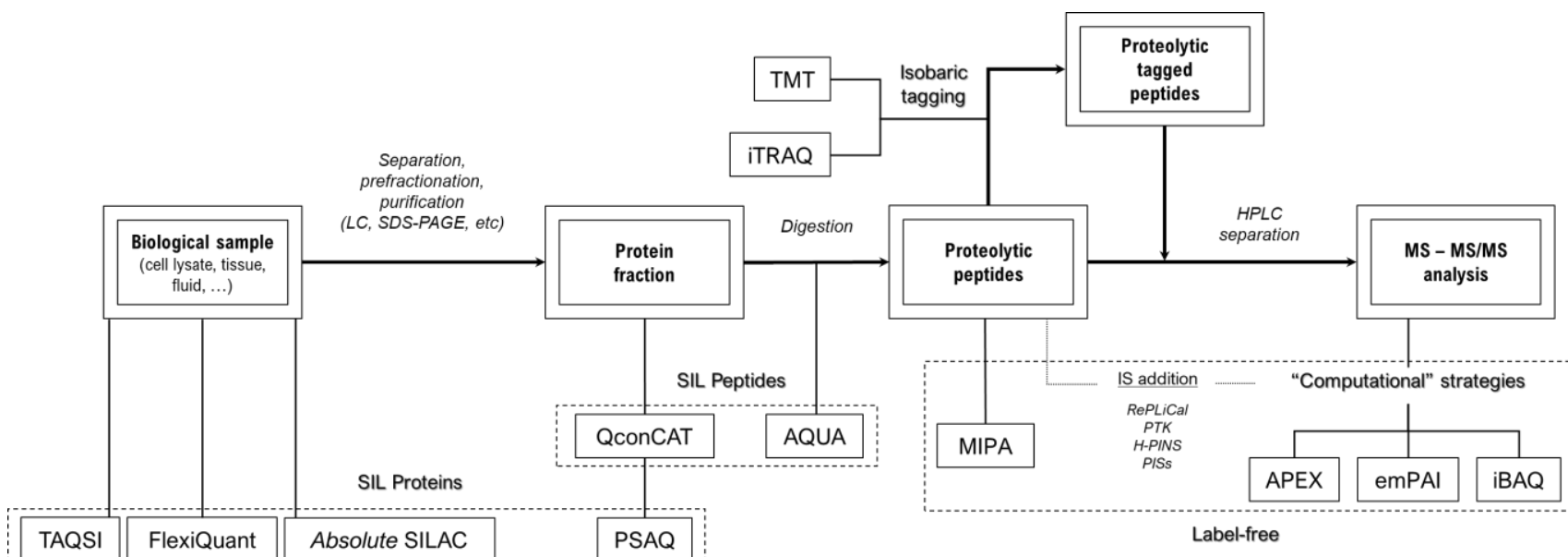

4 Figure 1. Timeline of standard addition in the main absolute protein quantification strategies with molecular MS during a model quantitative proteomics analysis workflow, adapted from (Malmström et al. 2009, Wang et al. 2016).

A

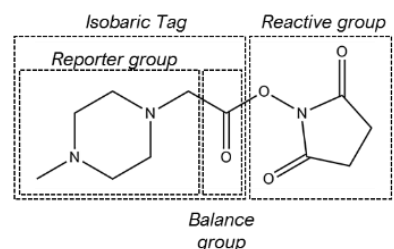

B

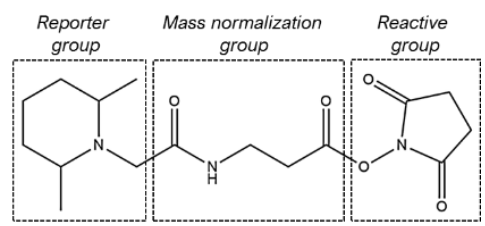

Figure 2. Isobaric tags for peptide/protein quantification. A) iTRAQ reagent, adapted from (Ross et al. 2004). The reactive group is usually based on $\mathrm{N}$-methylpiperazine, and can have up to four ${ }^{13} \mathrm{C}$ and two ${ }^{15} \mathrm{~N}$, the mass balance group is a carbonyl group with can have up to two ${ }^{13} \mathrm{C}$ and two ${ }^{18} \mathrm{O}$, in such a way that the overall mass of the isobaric tags are the same. The reactive group is usually based on a NHS ester group that reacts with the peptides amines forming an amide bounding. B) Tandem mass tag reagent, adapted from (Dayon et al. 2008). Similarly, to iTRAQ reagents, it comprises a reporter group (detected by MS) and a mass normalization group, of identical overall mass in the different reagents, and a reactive group. The reactive group is commonly an amine reactive group, although TMTs bearing carbonyl reactivity have been reported though hydrazide- and aminooxy-functionalized reactive groups (Hahne et al. 2012). 


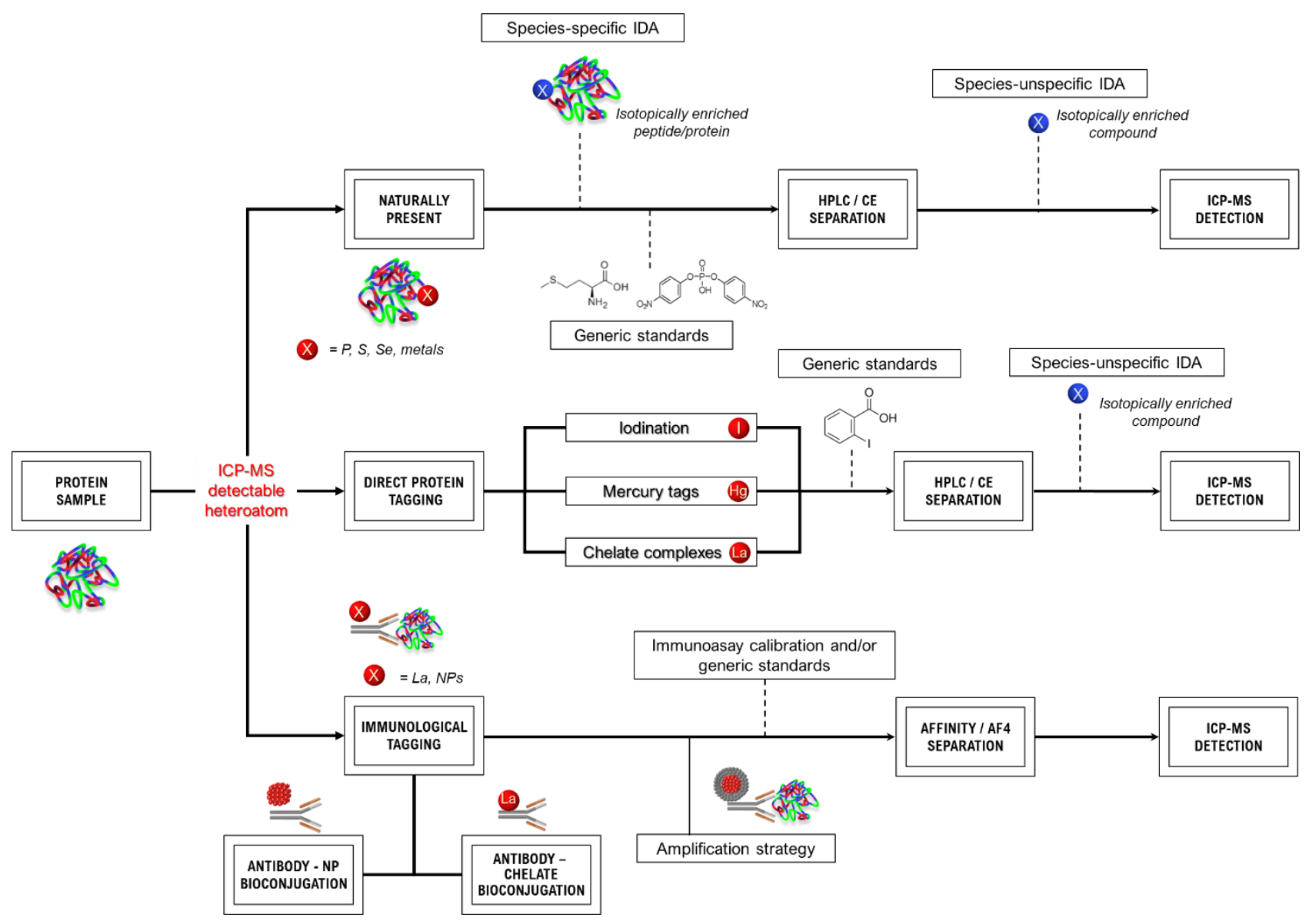

2 Figure 3. ICP-detectable heteroatom source and standardization timeline in the main elemental MS-based absolute quantitative 3 proteomics strategies.

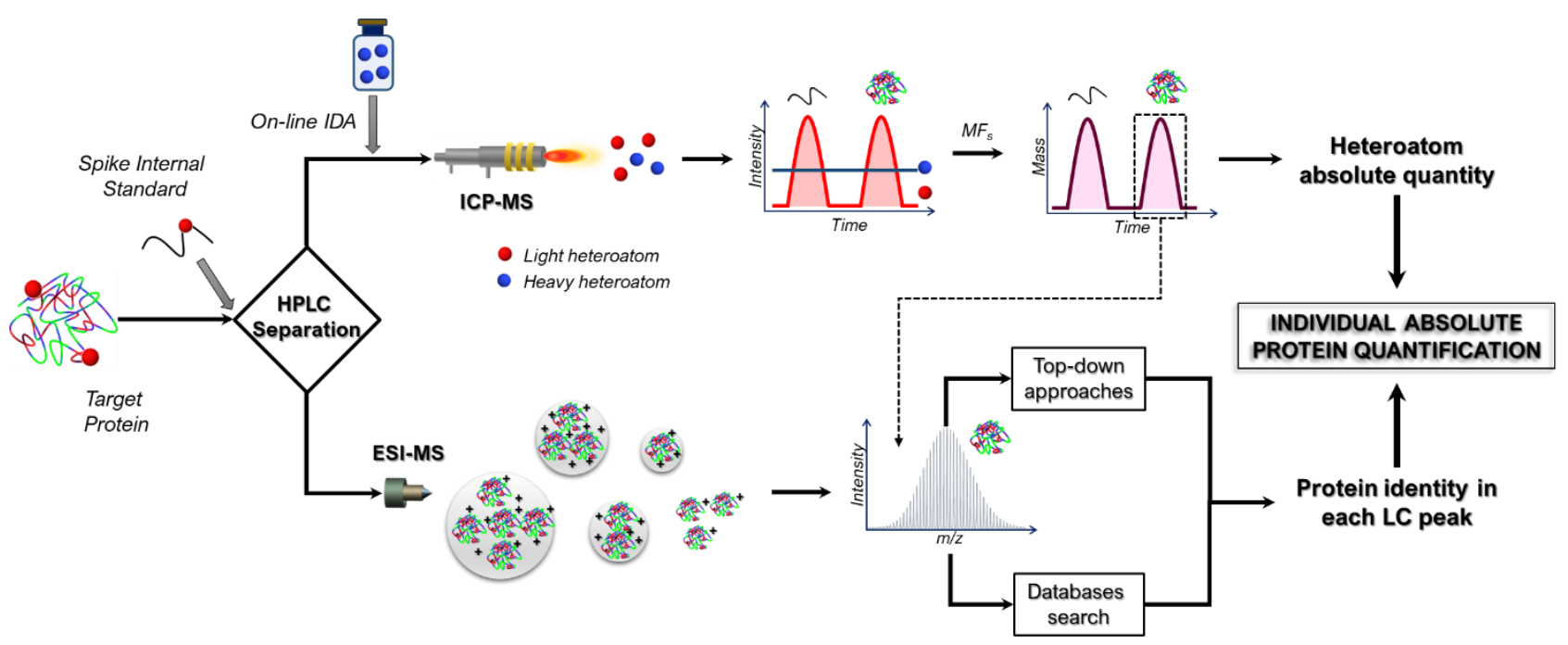

Figure 4. Scheme of an "absolute" quantitative proteomics workflow based on combining elemental and molecular MS detection after identical separation (HPLC) conditions, adapted from (Calderón-Celis et al. 2016). ICP-MS: the sample containing the sought analyte is spiked with a species-unspecific standard containing the detected heteroatom. After LC separation, heteroatom absolute content of the standard and the analyte(s) is accomplished by on-line isotope dilution analysis (mass flow equation, MF $F_{s}$. Figure 7.C) by relating the peak areas of the standard (of known concentration added to the sample to correct for injection errors and simplify IDA computations) and the analytes. ESI-MS: the detection of the analyte species provides their identification and/or sequence characterization, either with MS and MS/MS analysis (i.e., top-down workflow), or with accurate MS analysis together with database information. This provides the 
A

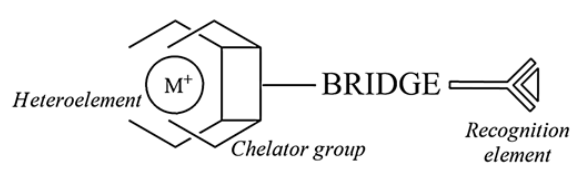

C

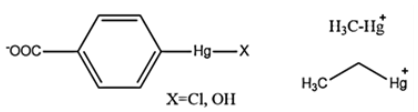

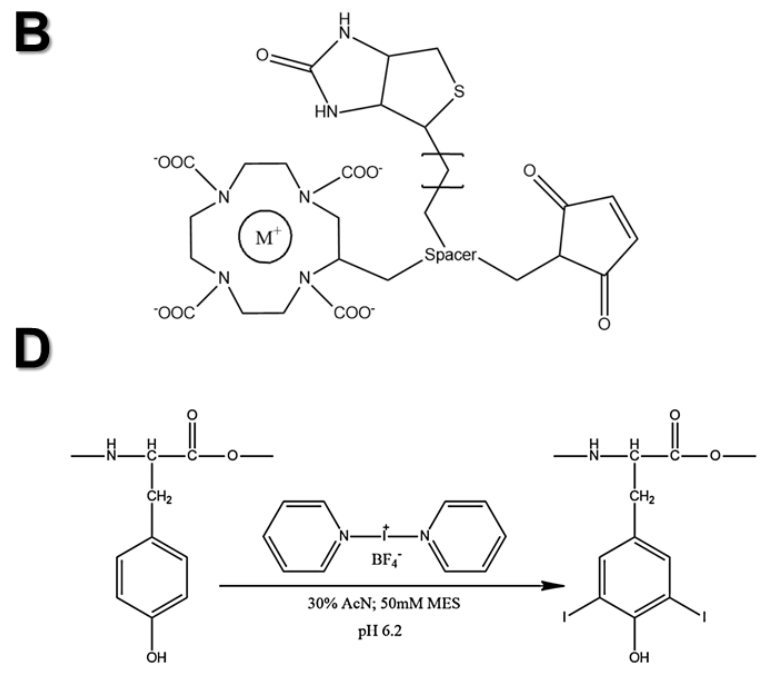

Figure 5. Chemical structures of labeling reagents in ICP-MS approaches. A) Scheme of bifunctional reagents, which consist on a chelating group that bonds the ICP-MS detected heteroelement (mostly metals), a bridge or main body of the reagent, and a recognition group that reacts to the sought analyte. B) Schematic representation of MeCAT reagent, adapted from (Ahrends et al. 2007). It contains a DOTA macrocycle for metal chelating, a spacer that connects the macrocycle and the maleimido reactive group that specifically reacts to thiol groups. The spacer might contain a biotin group for purification. C) Mercury tags: p-chloromercurybenzoate, $p$ hydroxymercurybenzoate, methyl-mercury, ethyl-mercury, adapted from (Tholey and Schaumlöffel 2010). D) lodination reaction using bispyridinium iodinium tetrafluoroborate as reactive agent, adapted from (Pereira Navaza et al. 2009). 


$$
\text { A }
$$
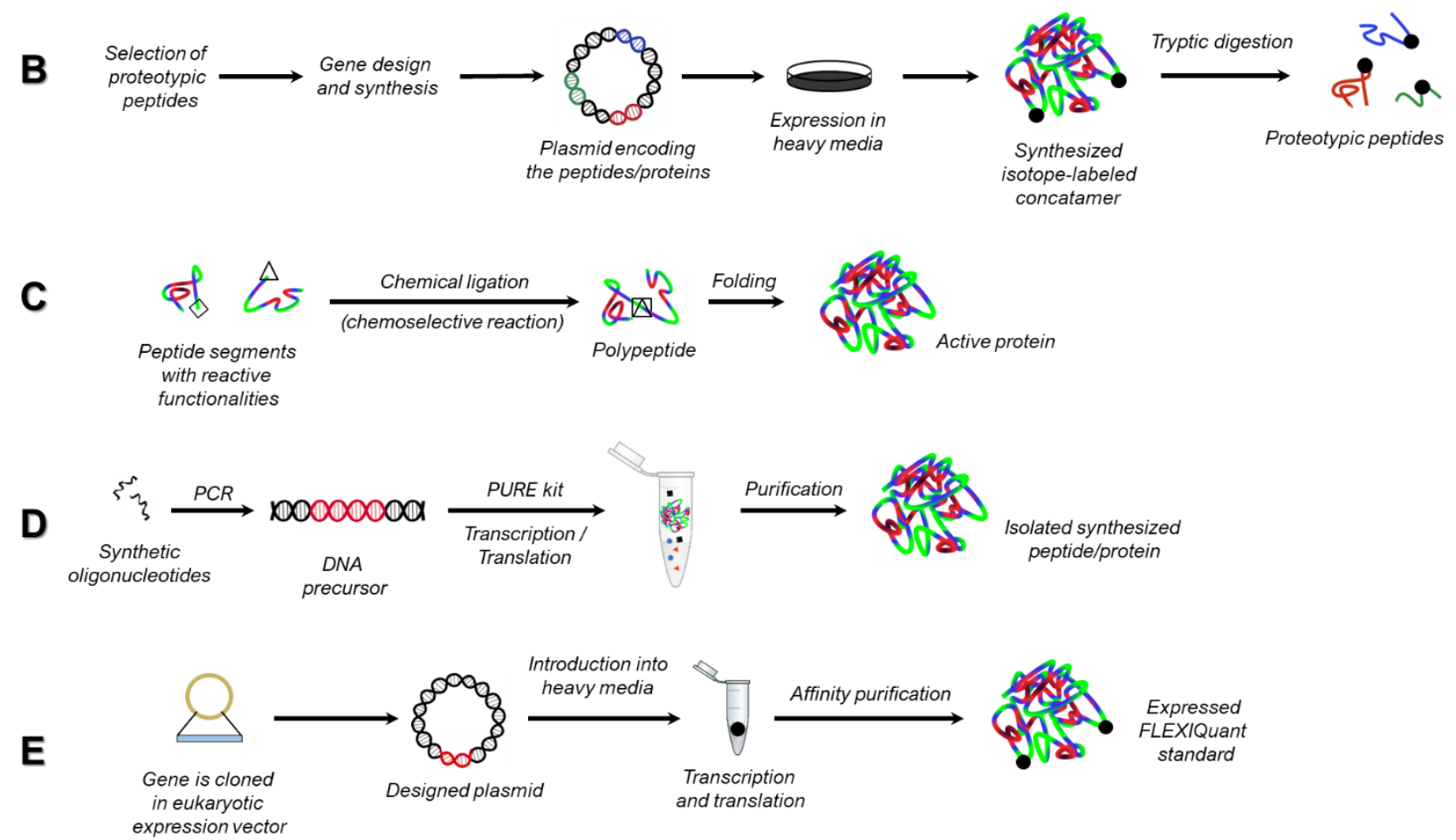

Figure 6. Strategies of peptide/protein standards synthesis: A) Chemical synthesis based on solid phase supports (SPPS), adapted from (Amblard et al. 2006). The amino acids are added in excess in order to assure maximal yield and in the desired order in each step of the synthesis. They are $\mathrm{N}$-terminal protected, usually with tert-butyloxycarbonyl (t-Boc) or $9 \mathrm{H}$-fluoren-9-ylmethoxycarbonyl (Fmoc) groups, in order to prevent self-coupling of the amino acids to compete with the peptide chain synthesis. The assembling process is usually controlled by monitoring with spectrophotometry the amount of Fmoc removed at each deprotection/coupling cycle (Coin et al. 2007), whereas the synthesis process can be controlled by measuring quantitatively the peptide chain or the unreacted free amino acids by the ninhydrin reaction (Sarin et al. 1981).Deprotection step is usually carried out with TFA when BOC is the protecting group and with Piperidine/DMF when it is FMOC. Cleavage step is usually carried out with high concentration of TFA, together with phenol and TIPS. B) Metabolic synthesis through concatemerization. Firstly, the proteotypic quantification peptides that correspond to the target proteins are selected and synthesized together as a single protein through the corresponding synthetic designed gene. Gene expression can be performed in a medium that contains isotopically enriched lysine and arginine to produce isotope-labeled standards. C) Chemical ligation through chemoselective reaction for the union of peptides, adapted from (Dawson and Kent 2000). D) Metabolic synthesis with the PURE system, adapted from (Xian et al. 2016). From the synthetic DNA precursor (previously amplified by PCR from synthetic oligonucleotides), the sought peptide or protein is synthesized with the PURE kit, which contains the required isolated enzymes, amino acids (which can be isotopically labeled), ribosomes, and RNAs. All recombinant protein components of the system are His-tagged, allowing purification of the synthesized untagged protein by removing the rest of the system's components. E) FLEXIQuant synthesis strategy, adapted from (Singh et al. 2012). The gene of interest is cloned into a wheat germ expression vector, and transcribed and translated in a wheat germ extract (WGE) in the presence of selected heavy isotope-labeled amino acids $\left(\left[{ }^{13} \mathrm{C},{ }^{15} \mathrm{~N}\right]\right.$ arginine and lysine), which provides the in vitro expression of the full-length labeled protein standards. 
A

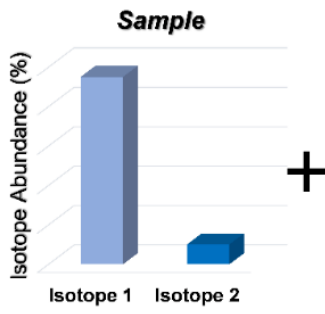

B
Spike

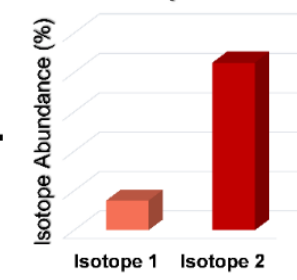

C
Mixture

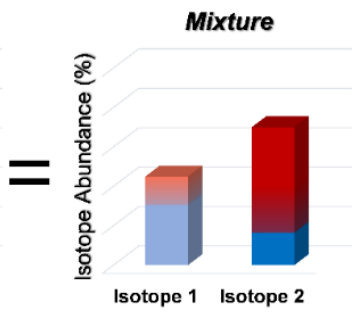

Figure 7. A) Concept of isotope dilution, adapted from (Rodríguez-González et al. 2005). A sample with natural isotopic abundance of the target compound or element is mixed with a spike isotopically enriched in a non-abundant isotope in a known isotopic composition. The final mixture is analyzed, the concentration of the sample can be calculated from the abundances of the measured isotopes. B) Isotope dilution equation in species-specific IDA approaches that express the moles of target element in a sample (s), as a function of the moles of element in the isotopically enriched spike (sp), the experimental ratios of two isotopes (1 and 2) of the element in a mixture of sample and spike (Rm), and the element isotopic abundances in the sample, $A_{s}^{1}$ and $A^{2}$ (i.e. IUPAC isotopic abundances), and in the spike, $A_{S p}^{1}$ and $A_{S p}^{2}$ (therefore requiring previous characterization). C) Mass flow equation for species-unspecific IDA approaches. The sample's 9 mass flow (MFs) is expressed as function of the element concentration in the spike (Csp), the density and flow of the spike (dsp and fsp),
10 the atomic weights of the element in the sample and the spike (Aws and Awsp), $R m, A_{s}^{1}, A_{s p}^{2}$, and the isotope ratios in the sample and 11 spike (Rs and Rsp), adapted from (Rodríguez-González et al. 2005). 